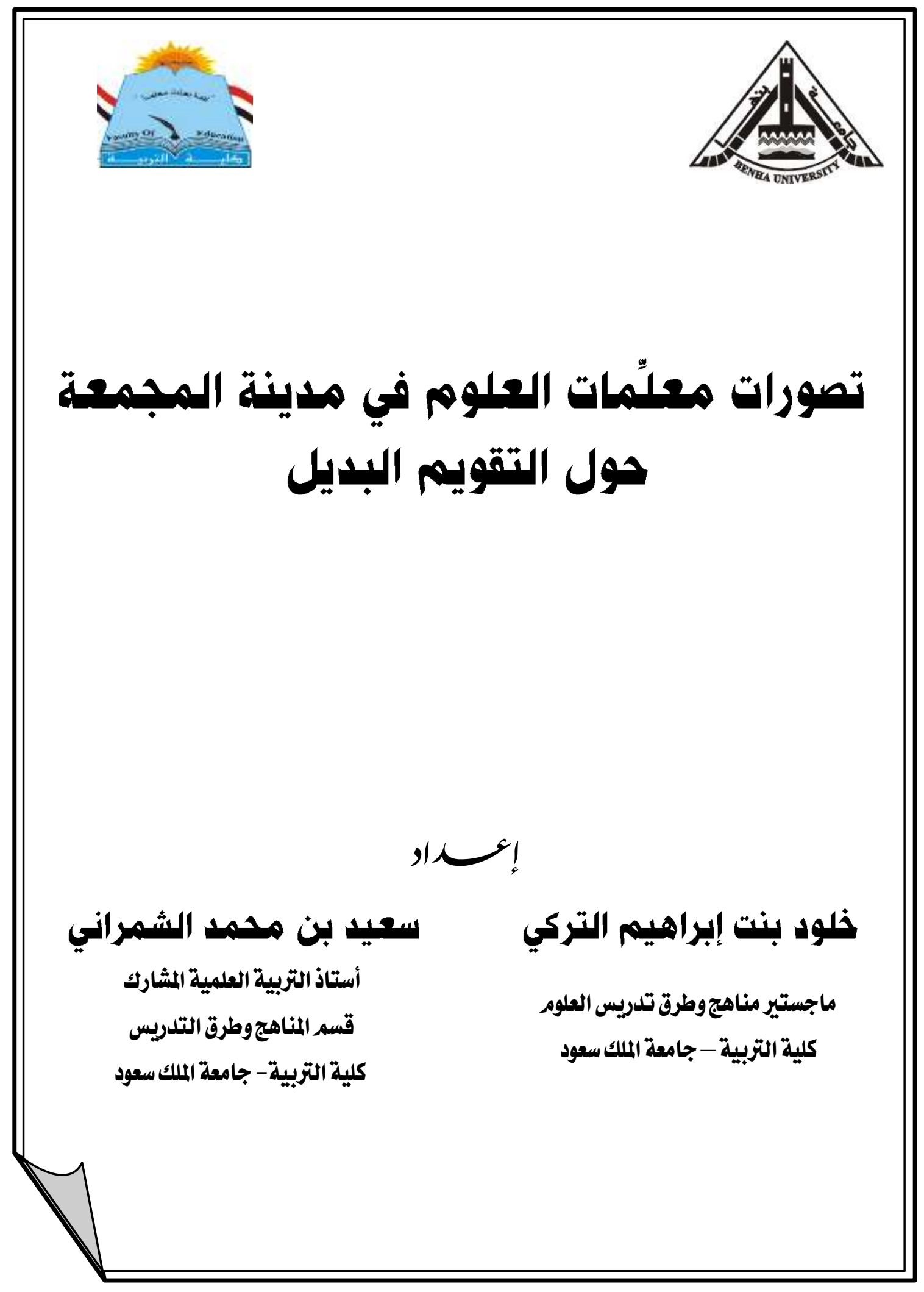




\section{تصورات معلِّمات العلوم في مدينة المجمعة حول التقويم البديل}

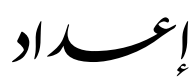

\section{سعيد بن محمد الشمراني}

أستاذ التربية العلمية المشارك قسم المناهج وطرق التدريس

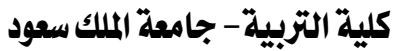

خلود بنت إبراهيم التركي

ماجستير مناهج وطرق تلديس العلوم

كلية التربية - جامعة الملك سعود

\section{الملذثم}

هَدَتَ البحث لاستقصاء تصورات معلمات العلوم في مدينة المجمعة حول التقويم البديل

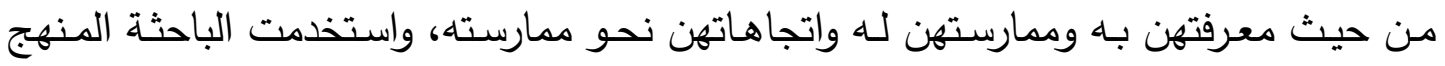

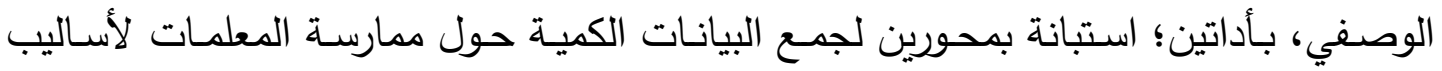

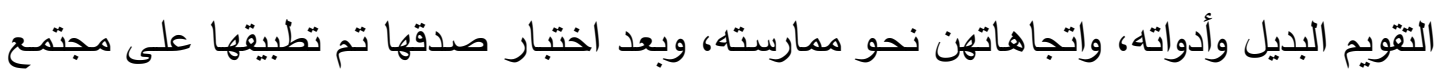

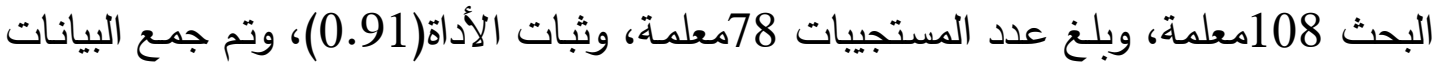

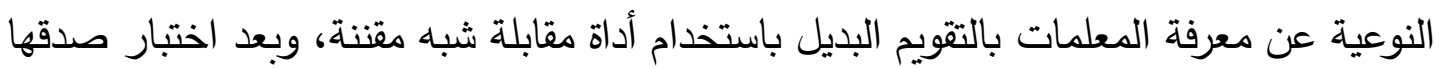
تم تطبيقها على 10معلمات.

أظهـرت النتائج أنَّ مستوى ممارسـة المعلمـات لأسـاليب التقويم البديل وأدواتـه عـالٍ

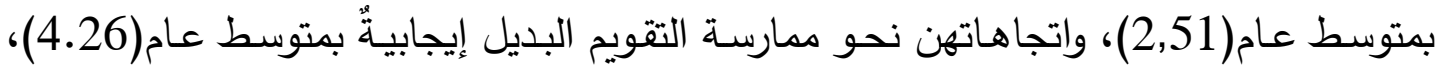
وتبيَّن وجود علاقـة ارتباطيـة متوسطة بين اتجاهـات المعلمـات نحو ممارسـة التقويم البديل

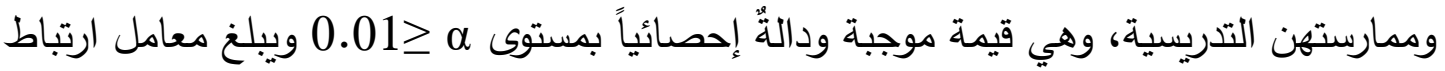

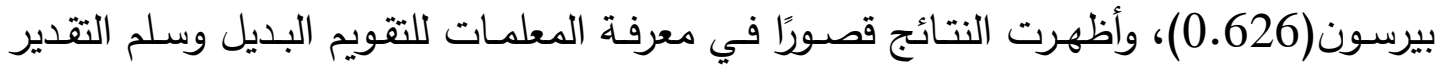

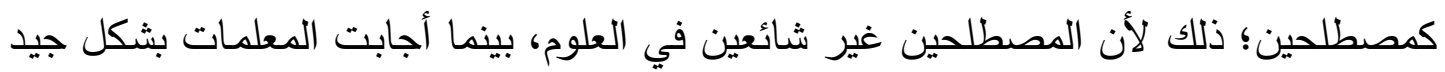

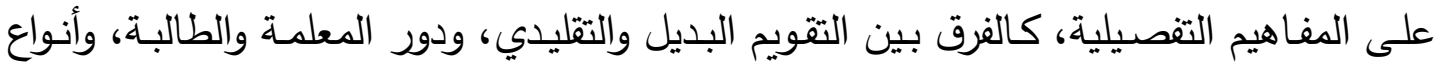
أساليب التقويم البديل، وهذا مرتبط بممارستهن التدريسية؛ مما يعني أنهن يمارسن التقويم البديل

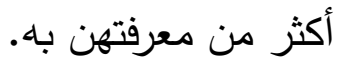
وعليه؛ قُِّّمت عدد من التوصيات، منها رفع مستوى معرفة معلمات العلوم بمصطلح التقويم البديل وممارستهن له، من خلال دورات تدريبية تتضمن المصطلح والأساليب والأدوات. الكلمات المفتاحية: تصورات المعلمات- التقويم البديل- ممارسة المعلمات- اتجاهات المعلماتمعرفة المعلمات. 


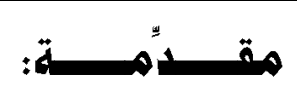

يُعد التقويُُ ركناً أساسياً من أركانِ العملية التعليميَّة وجزء لا يتجزأ منها، ويعتبر نجاح

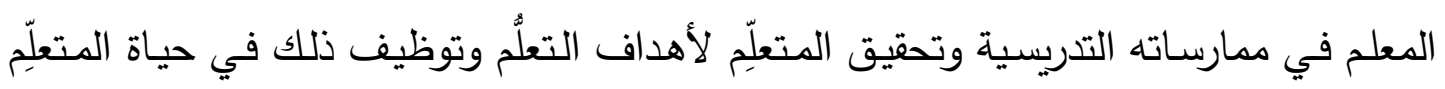
اليومية من أهم منطلبات العملية التعليميَّة. ولقد عدَّ كثيرٌ مِن التربويين - ولفترةٍ طويلة من الزمن في المدرسة السلوكية - تقويًَ

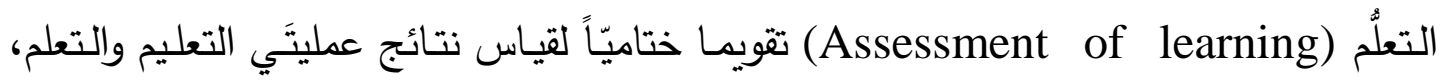

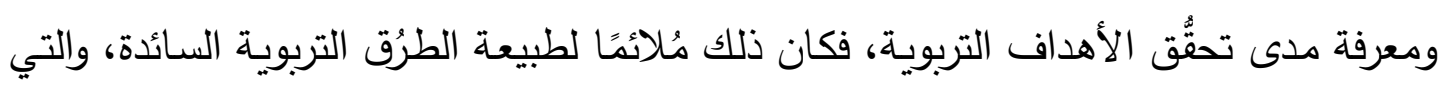
ركزت على الحِفْظ والاستظهار والتلقين.

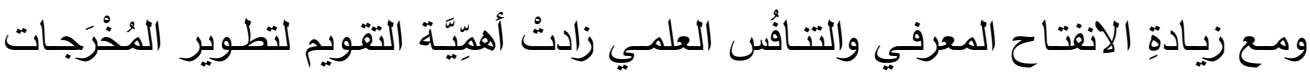

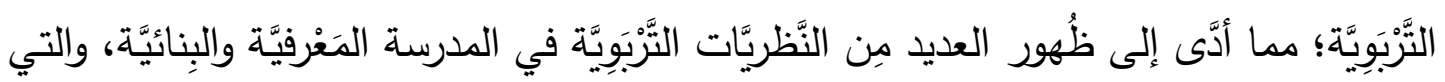

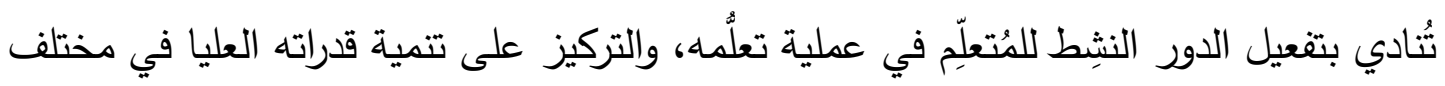

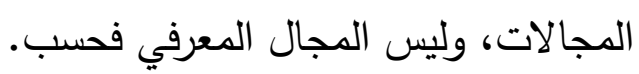

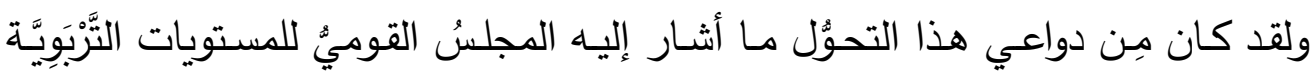

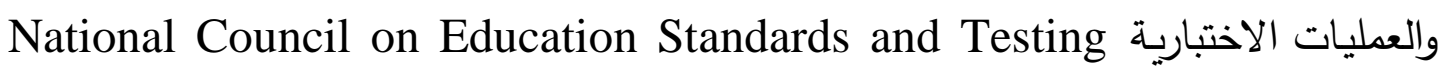

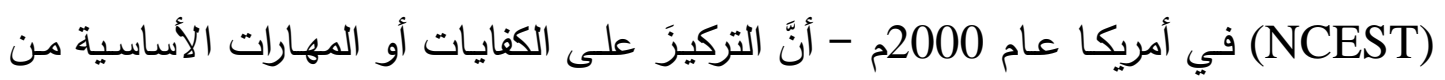

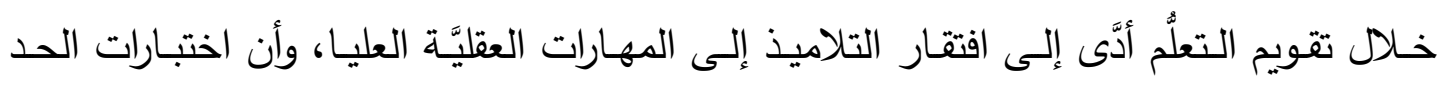

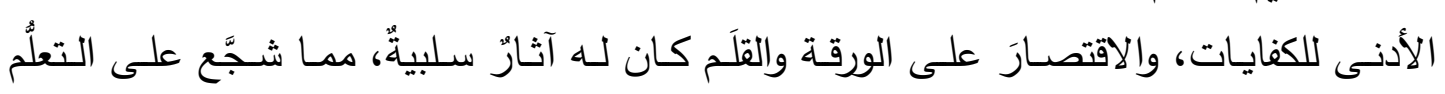

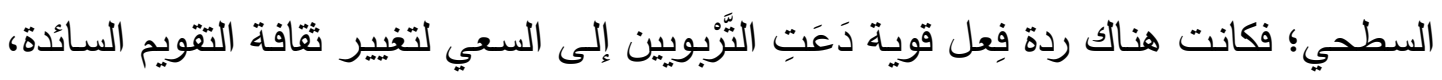

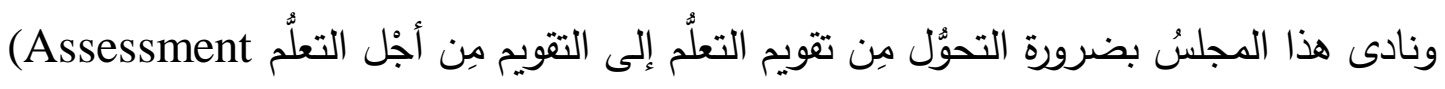

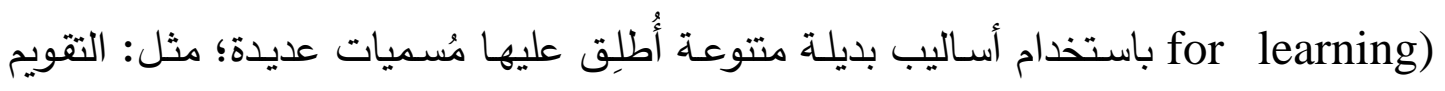
الحقيقي، والتقويم المستتد إلى الأداء، والتقويم البديل وغيرها؛ (Olson,1995).

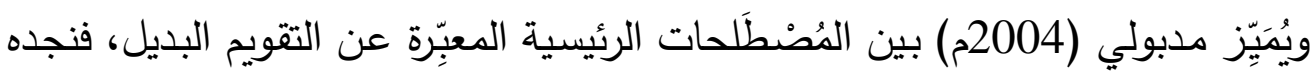

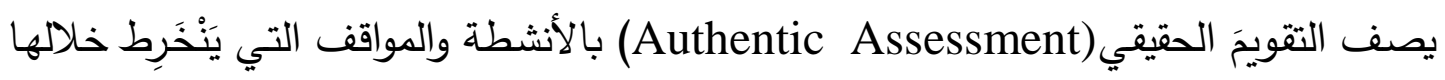

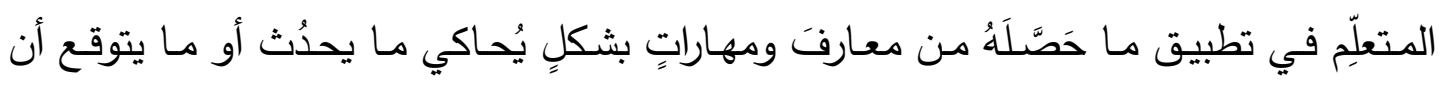
يحدثَ في مواقف الحياة الحقيقية، في حين يعرِّف التقويم المُسْتَّدِ إلى الأداء (Performance)

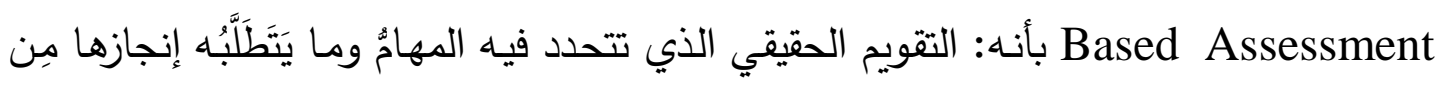


أداء مَوْصُوفٍ بشكل تفصيلي، بما يسمح بملاحظة المتعلم أثناء القيام بأدائه مطبقًا وموظفًا لما تعلمه مِن معارف.

بينما يُشير التقويُُ البديل (Alternative Assessment) إلى كلِّ ما هو مُغاير لما

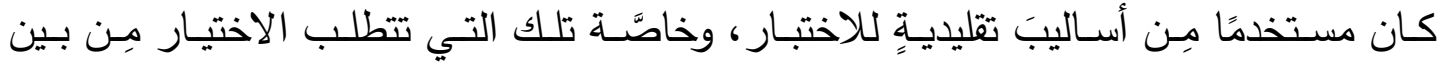
استجاباتِ سابقة التجهيز (الاختيار من متعِدِّ). ويُعَرِّف ميلر (Mueller,2014) التُقويم البديل

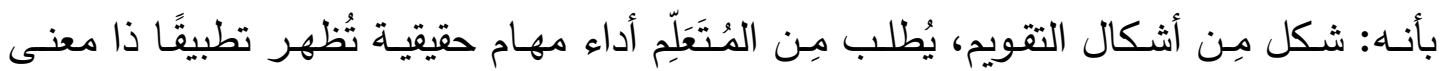
لمعارف والحقائق الأساسية.

ويُعرفه البلاونة (2010م) بأنه: "التقويم مِن خلال تقديم مهام أدائية تُمَتِّل مواقف حياتيةً

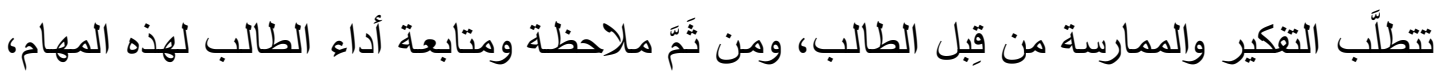

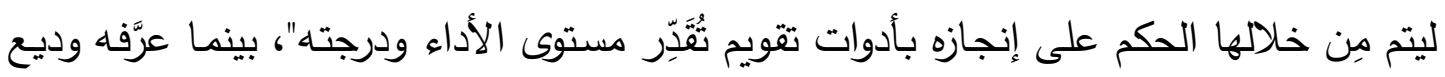

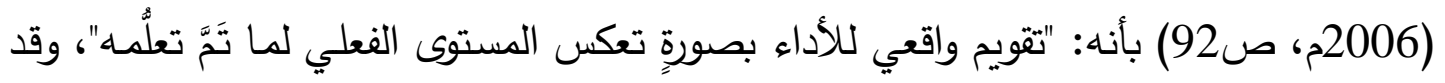

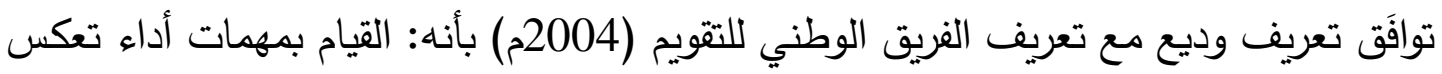

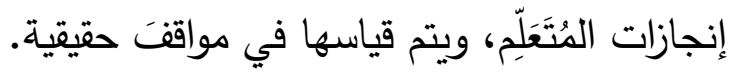

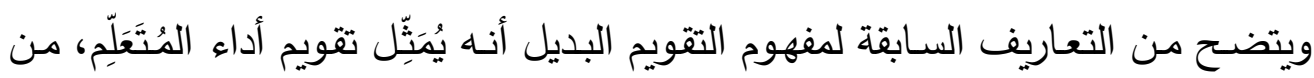

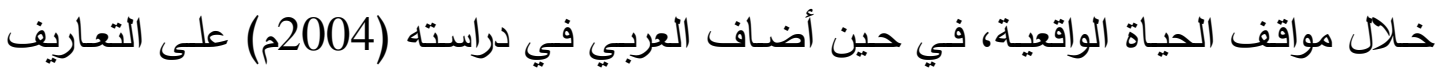

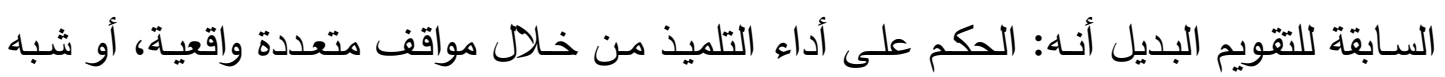

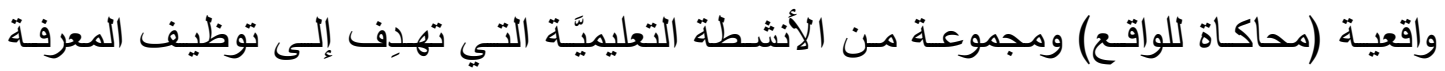
واختبارها على فترات منتظمةِ، ليكونَ بذلك أكثر شُمُولية.

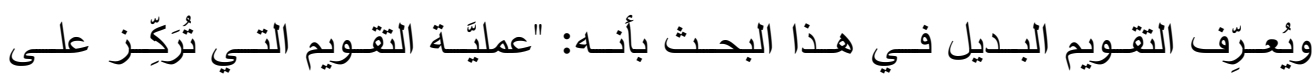

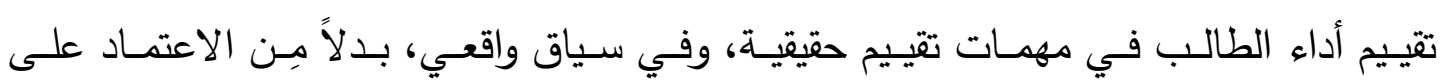
الأساليب التقليدية للتقييم".

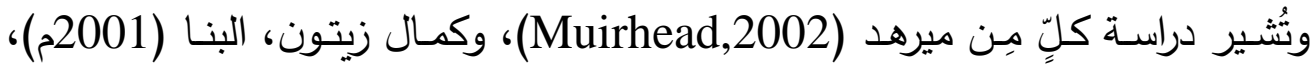
والفريق الوطني للتقويم (2004م)، والعصفور (2006م) إلى أهم أهداف التقويم البديل، والتي

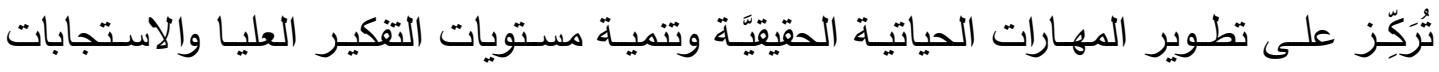

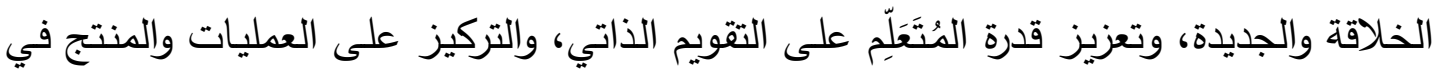

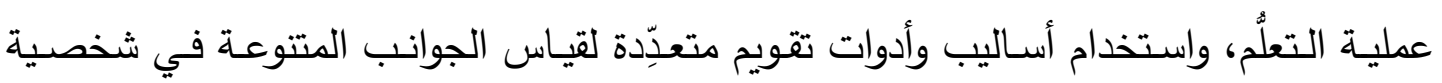




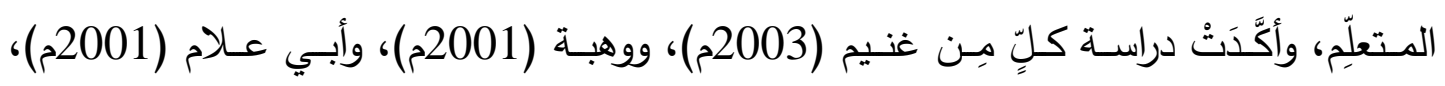

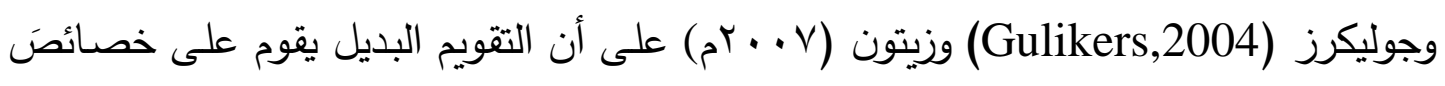

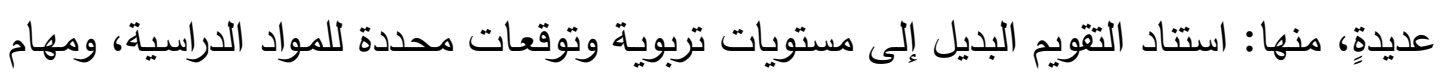

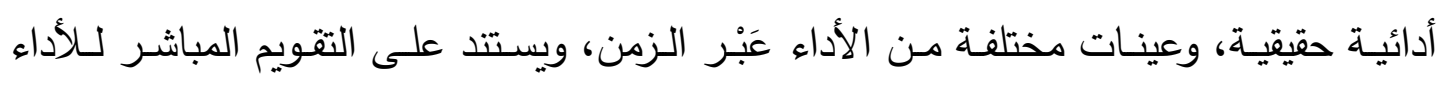
المتوقع، والتقويم القائم على المستويات. في حين أكدتُ دراسة الحمد (2004م) على أهمية امتلالك المعلم مهارةَ توظيف التقويم المعات

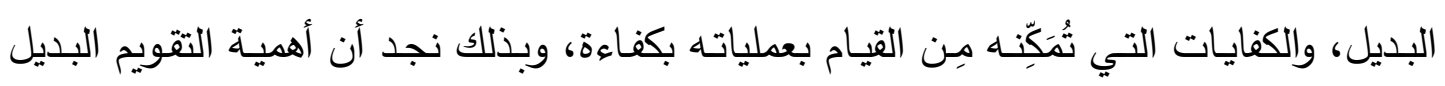

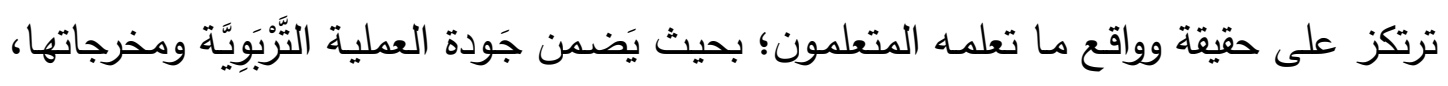

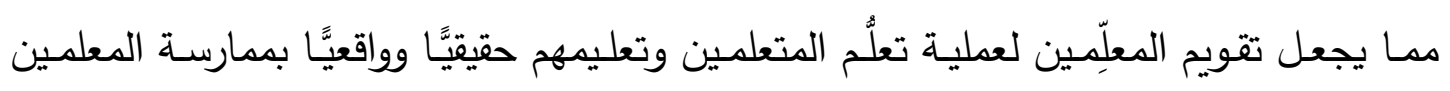

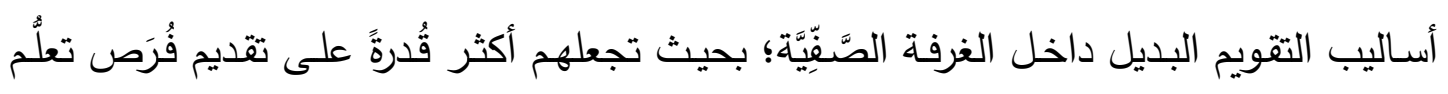

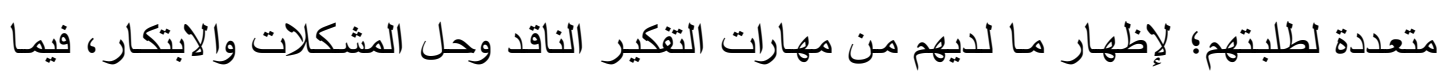

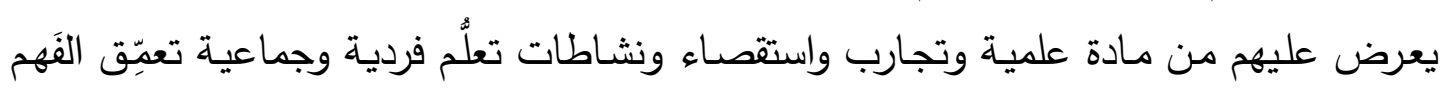

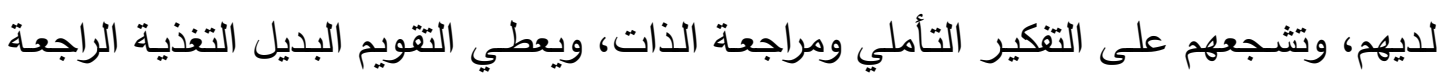

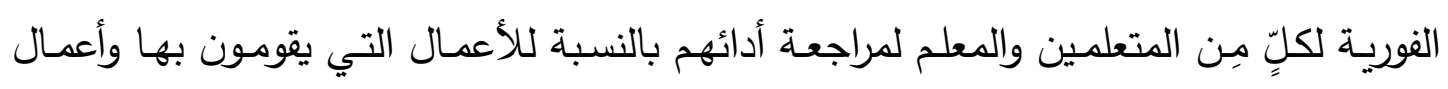
مشابهة لها.

وأظهرتْ ريفت (Wright, 1993) أن ممارسةً المعلمين لأساليب التقويم البديل تَزيد مِن إدراكهم لإنجازات طلبتهم، وكذلك تزيد مِن شُعورهم بالمسؤولية تجاههم.

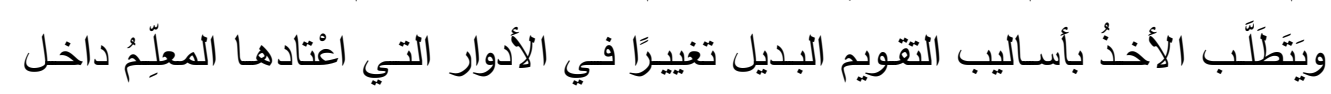

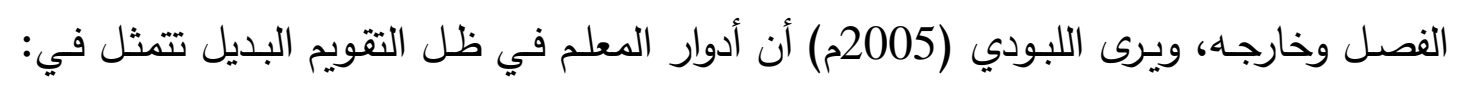
تصميم أدوات متتوعة ومُبتكرة للتقويم، واستخدام أساليب التقويم البديل - (مثل: ملفات الأعمال

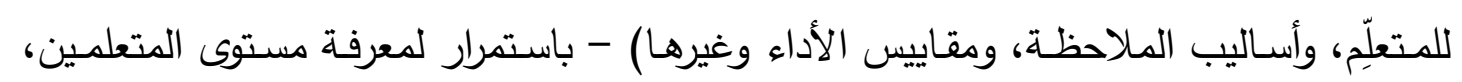

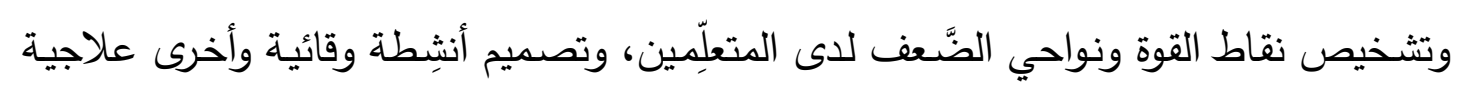

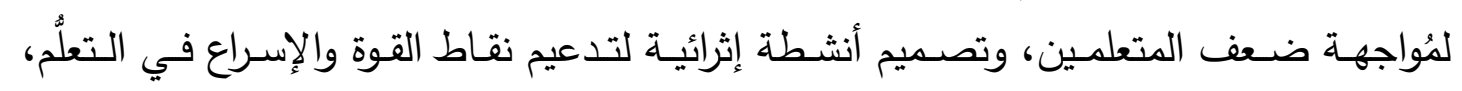

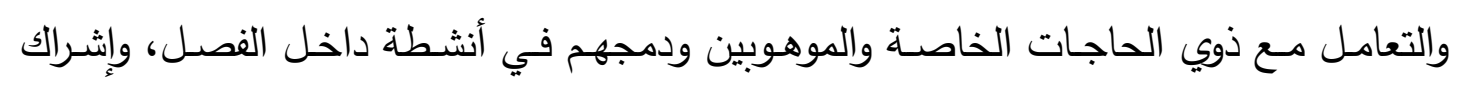

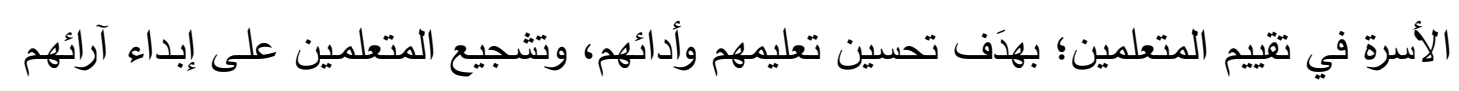
ومشاعرهم نحو ما درسوا في مواقف وأنشطة التعلُّم. 
وتتعدَّد أساليب وأدوات التقويم البديل وتختلف تبعًا لاختلاف المهام التي يراد تقويمها،

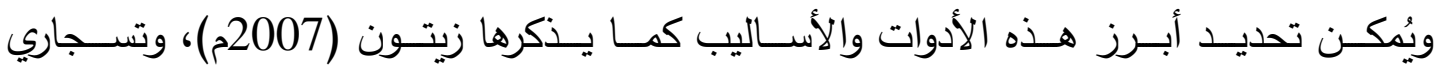

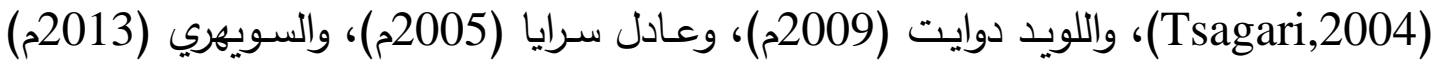

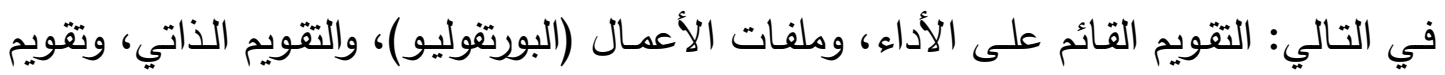

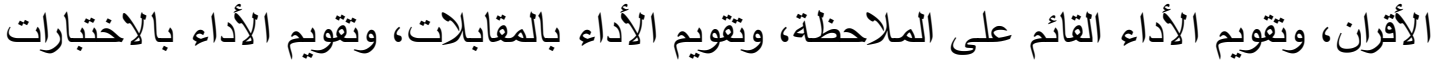

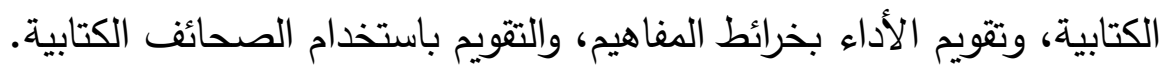

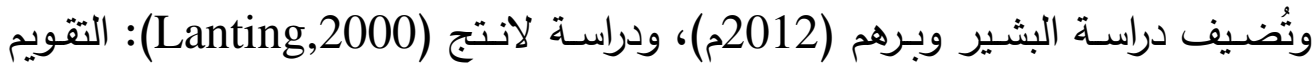
بالتواصل لزيادة وعي المتعلمين بما يَتَضَنَنُه التواصل من فعاليات (المؤتمر ، والمقابلة، والأسئلة

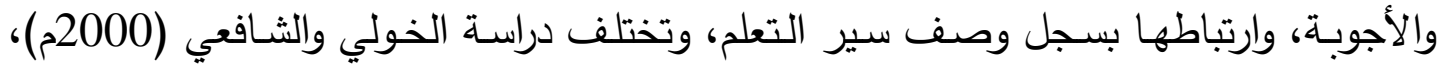

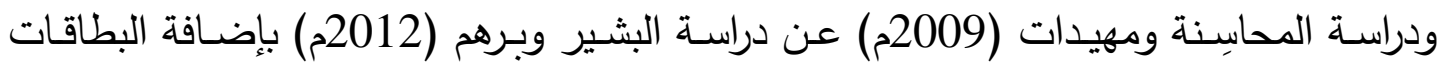
المُجَمَّعة والاسْتِبانة والعرض والإلِقاء.

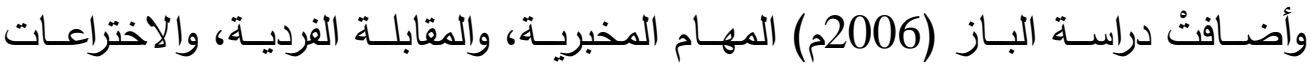

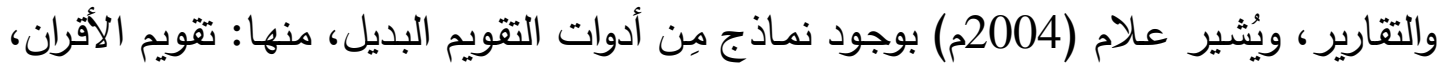
والتقويم الذاتي، وخرائط المفـاهيم، واختبارات مواقف المشكلات، واختبارات الكتاب المفتوح،

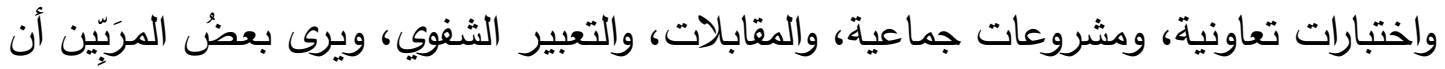

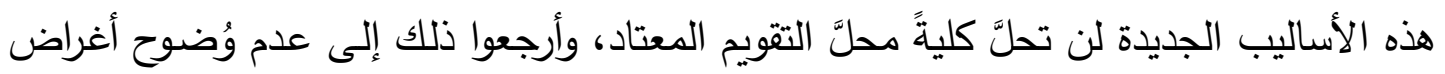
التقويم البديل؛ إذ يتطلب تحقيق هذه الأغراض أدواتٍ متتوعة.

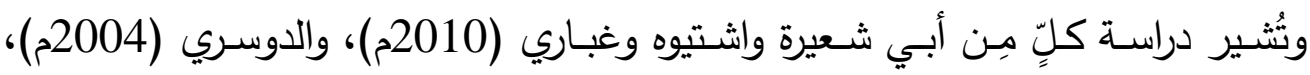
وحسن زيتون (2007م) بوجود عدة عقبات تُعيق تطبيق أساليب التقويم البديل وأدواته، ولا بد بد وند

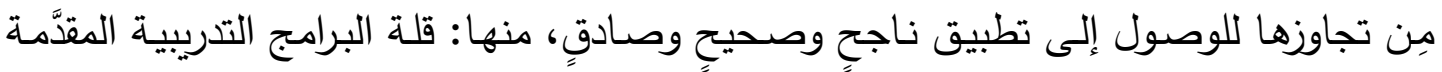
للمعلمين، وكثرة المتطلبات لتطبيقه؛ كالوقت والمال مِن جهة، والتصميم والتوظيف مِن جهةٍ أخرى، بالإضـافة إلى ضَسْف معرفة المعلمين ومهاراتهم بإجراءات التقويم البديل، وعدم تقبُّل

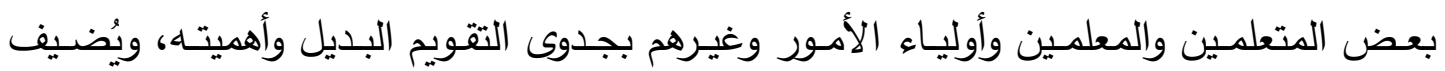

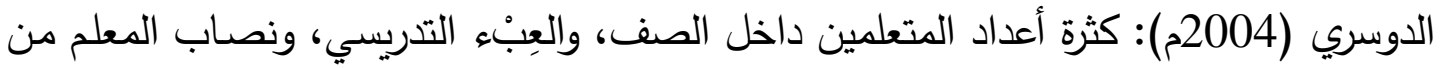




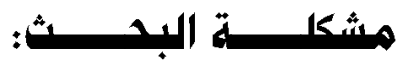

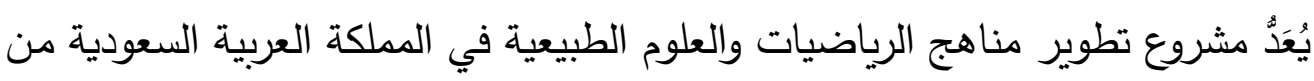

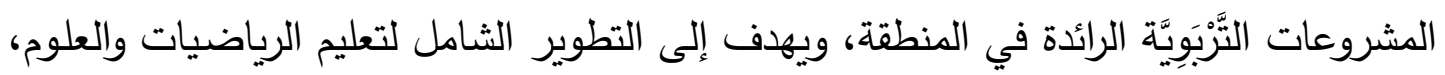

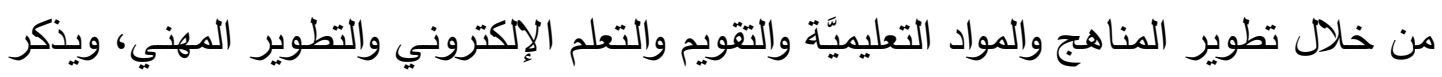

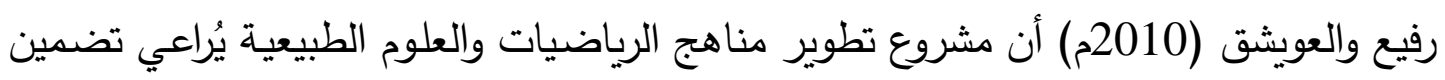

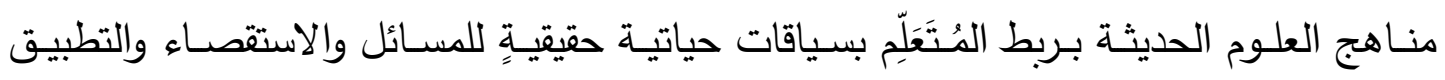

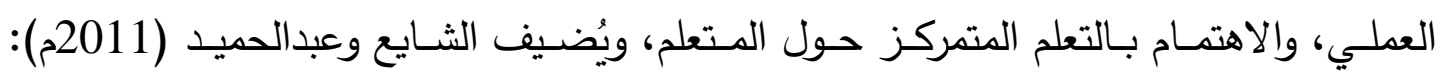

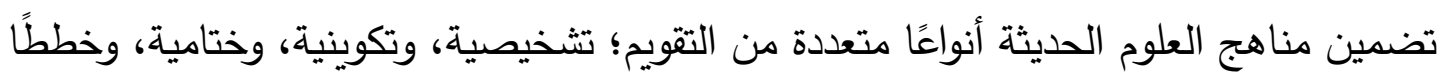

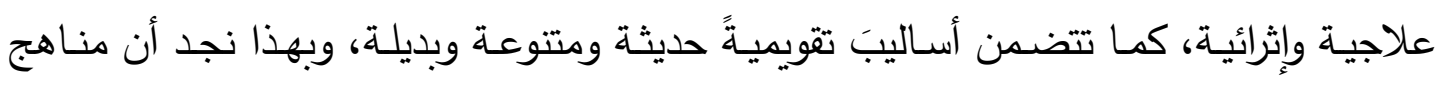
العلوم الحديثة تدعم التقويم البديل، مما يستوجب على المعلم والمعلمة مواكبة أحدث التطورات

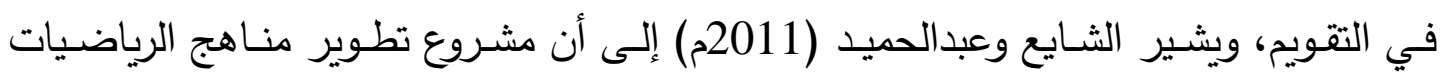

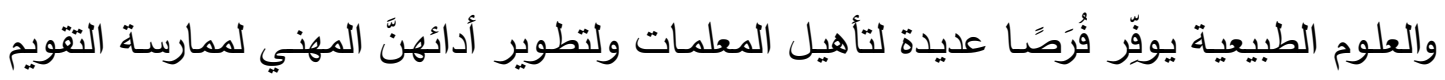

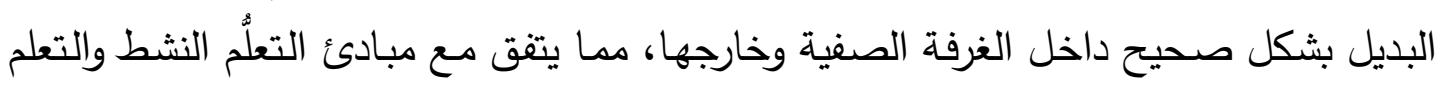
ذي المعنى والتعلم البنائي.

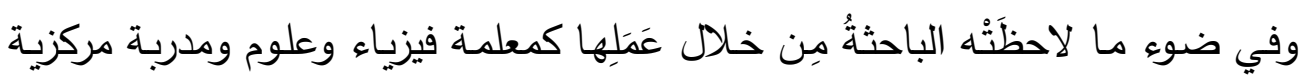

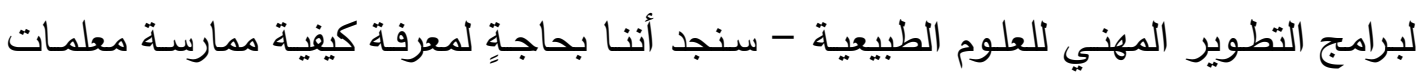

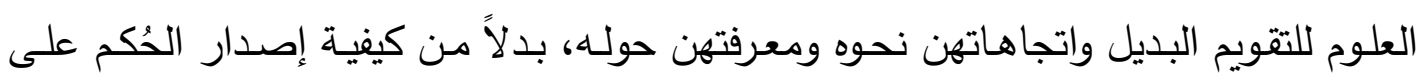

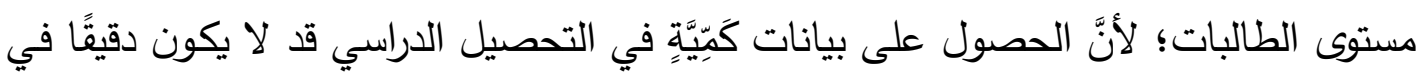

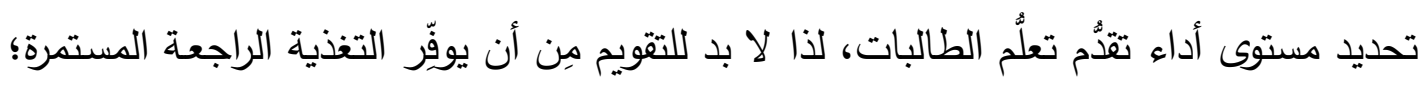

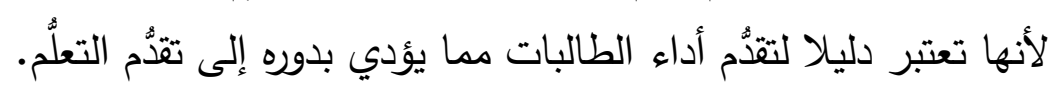

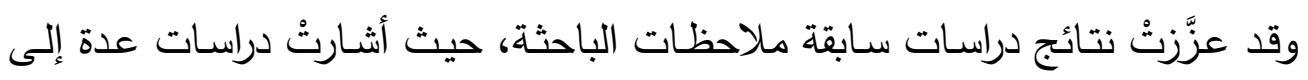

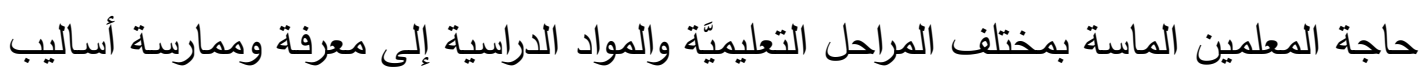
التقويم البديل، ومن بينها دراسة: مراد(2001م)، وكلبرتسن (Culbertsom,2000) وبيترسون

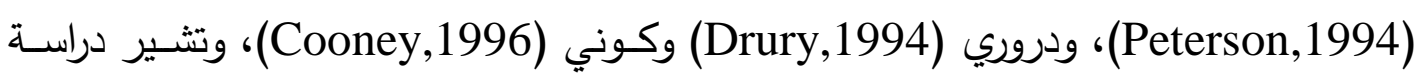

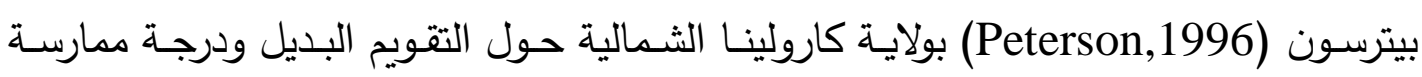
أساليب التقويم البديل في الفصول الدراسية إلى أن أكثر من نصف المعلمين المين لديهر غموض 
في فهم التقويم البديل، كما أوصت دراسـة عبد الباقي (2005م) بالاهتمام بأساليب التقويم الواقعي في الإعداد التربوي لمعلمي العلوم سواء قبل الخدمة أو أثناء الخدمة.

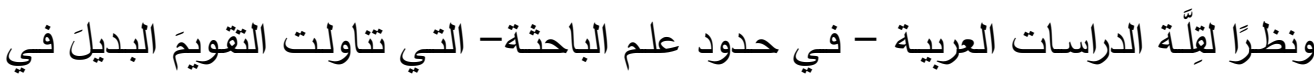
العلوم، فقد شعرت الباحثة بوجود حاجة لإجراء هذا البحث بهدف معرفة مستوى تصوُرات معلمات

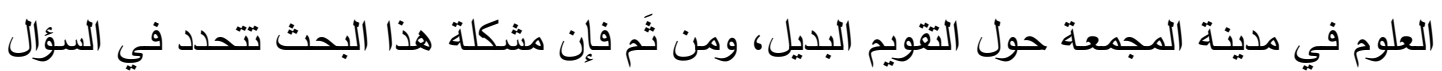

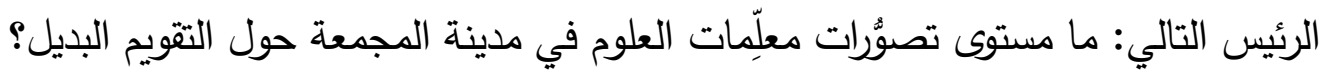

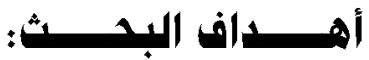

يهدف هذا البحث إلى التعرف على تصورات معلمات العلوم في مدينة المجعة حول

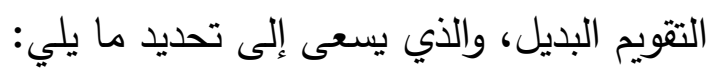

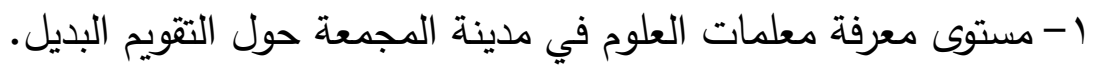
r- مستوى ممارسة معلمات العلوم في مدينة المجمعة لأساليب التقويم البديل وأدواته. ب- اتجاهات معلمات العلوم في مدينة المجمعة نحو ممارسة التقويم البديل. ع - مستوى ارتباط اتجاهات معلمات العلوم في مدينة المجمعة نحو ممارسة التقويم البديل

$$
\text { وممارستهن التدريسية. }
$$

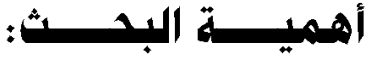 \\ يكتسب البحث أهميته من خلال ما يلي:}

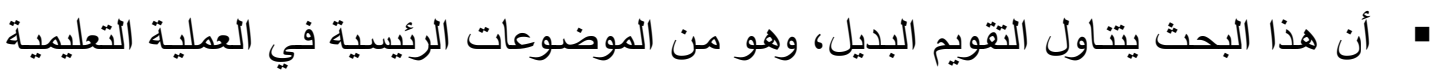

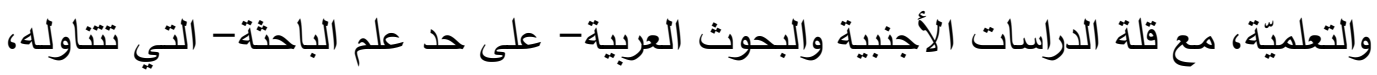

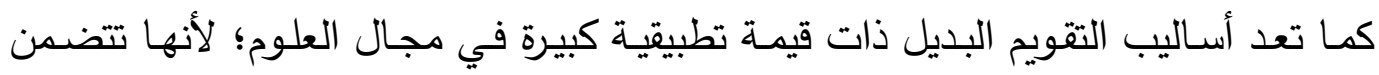
أنشطة حقيقية يمكن تنفيذها.

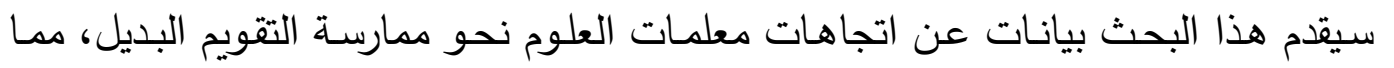

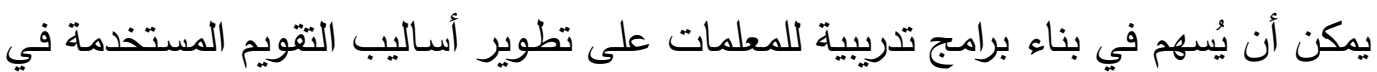

$$
\text { ضوء الاتجاهات الحديثة. }
$$

" سيوفر هذا البحث بعض المعلومات عن ممارسة المعلمات لأساليب التقويم البديل؛ مما قد

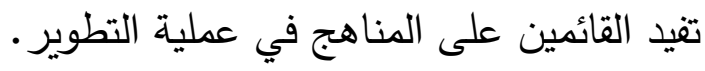
قد تفتح نتائج هذا البحث المجال في توجيه الباحثين والباحثات لإجراء دراسات استكمالاً لموضوع الدراسة من جوانب أخرى. 


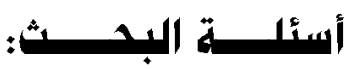

يحاول البحث الإجابة عن الأسئلة التالية :

1- ما مستوى معرفة معلمات العلوم في مدينة المجمعة حول التقويم البديل؟ الإنها r- ما مستوى ممارسة معلمات العلوم في مدينة المجمعة لأساليب التقويم البديل وأدواته؟

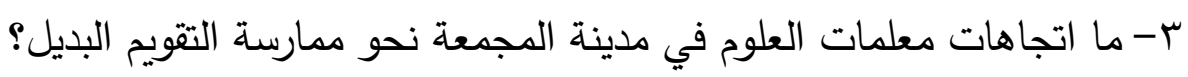

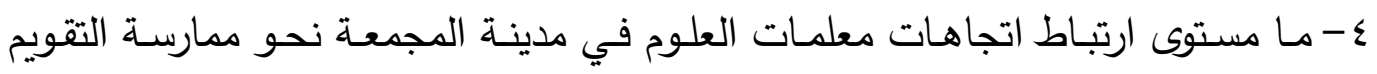
البديل وممارستهن التدريسية؟

\section{مود البد}

اقتصر البحث على استقصاء تصورات معلمات العلوم حول التقويم البديل في المدارس

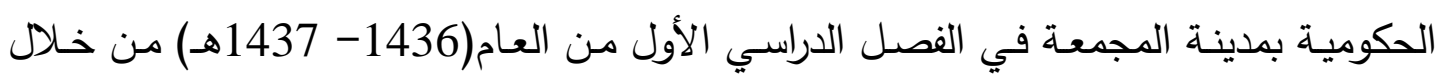
معرفتهن باه، وممارستهن لله، واتجاهاتهن نحو ممارسته.

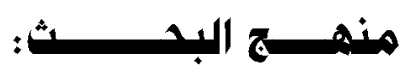

استخدمت الباحثة المنهج الوصفي للإجابة على أسئلة البحث، وهو المنهج الذي يهتم

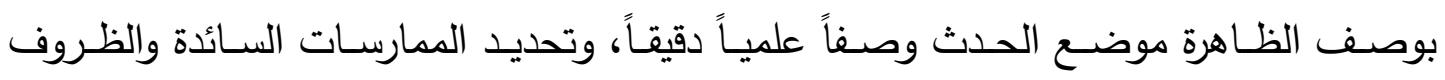
والعلاقات التي توجد بين الوقائع، والتعرف على المعتقدات والاتجاهات عند الأفراد والجماعات

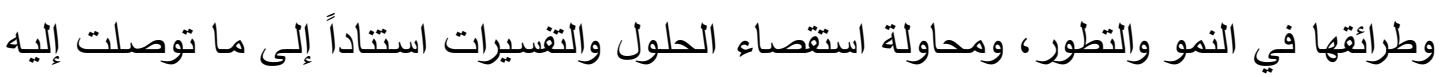

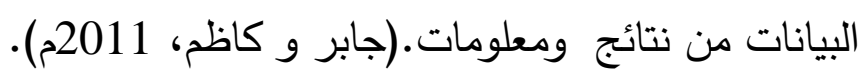

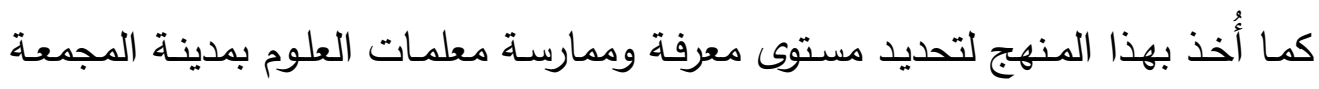
للتقويم البديل، واتجاهاتهن نحو ممارستهن له، وفي إطار هذا المنهج تم جمع البيانات الكمية والنوعية من خلال أداتين هما الاستبانة وبطاقة المقابلة.

\section{مصطاحسـات البدــث: \\ يتضمن البحث المصطلحات التالية:}

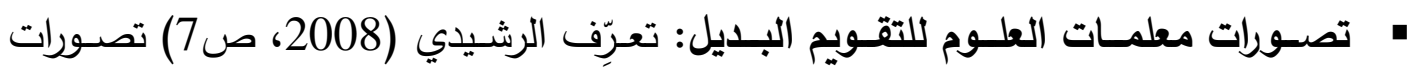

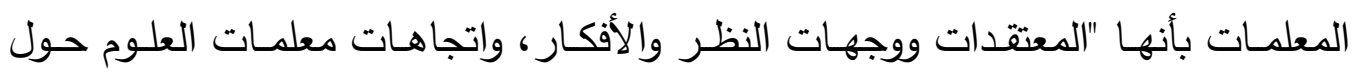

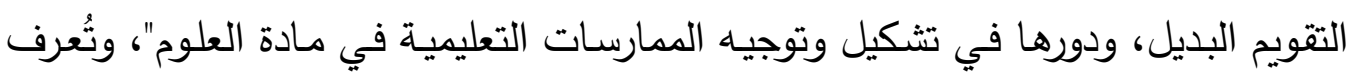


إجرائياً بأنها دراسـة الآراء والأفكار التي تحملها معلمات العلوم حول التقويم البديل من حيث معرفتهن به، ومدى ممارستهن للتقويم البديل، واتجاهاتهن نحو ممارسته.

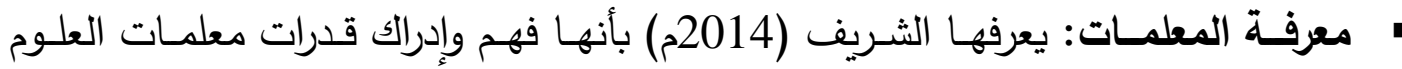
للأفكار التي يمتلكنها في مجال التقويم البديل لتحقيق الأهداف التربوية، وتُعرَّف إجرائياً

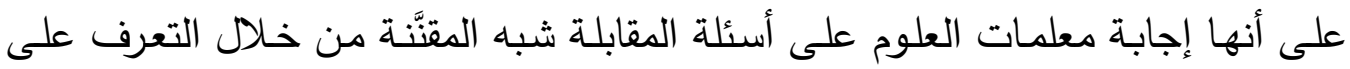
قدرتهن على فهم الدقصود من التقويم البديل، والفرق بين التقويم البديل والتقويم التقليدي، التئه

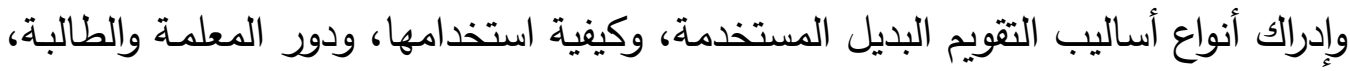

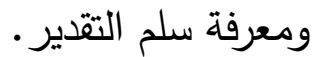

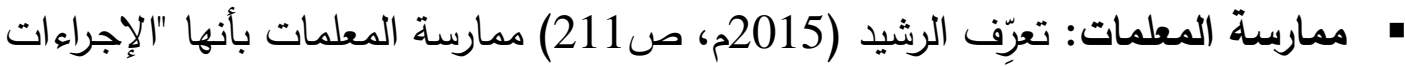

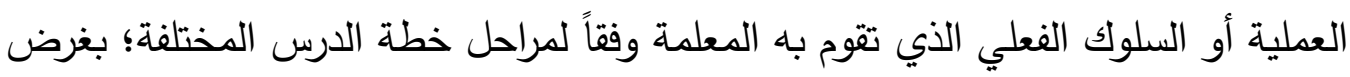

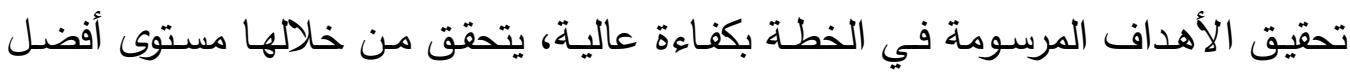
للتلميذة"، وتُعرف إجرائياً بالمستوى الذي تحصل عليه معلمات العلوم، من خلال الإجابة على الاستبانة ضمن المحور الأول الخاص بممارسة المعلمات لأساليب التقويم البديل

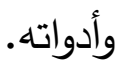

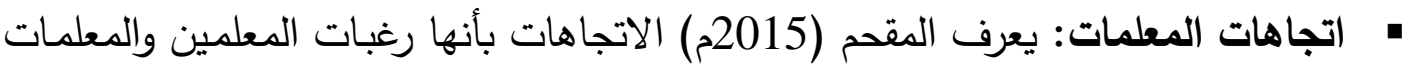

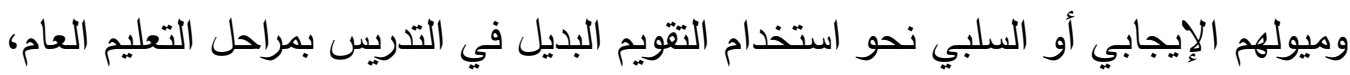

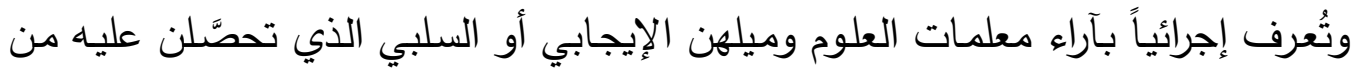

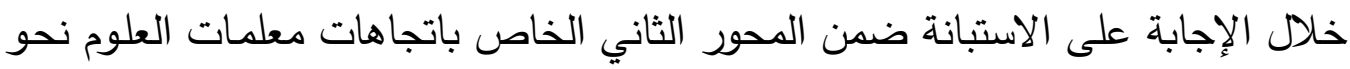

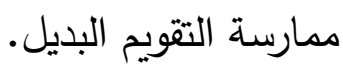
التقويم البديل: عرّف البلاونة (2010م) التقويم البديل بأنه التقويم من خلال تقديم مهام أدائية تمثل مواقف حياتية تتطلب التثكير والممارسة من قِبل الطالب، ثم ملاحظة ومتابعة أداء الطالب لهذه المهام، ليتم من خلالها الحكم على إنجازه بأدوات تقويم تقدر مستوى

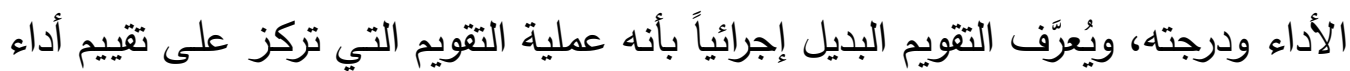

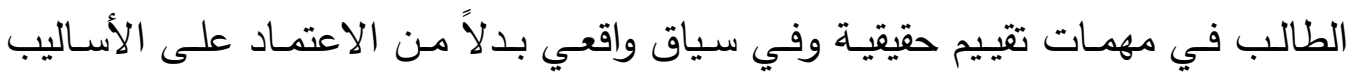
التقليدية للتقييم. 


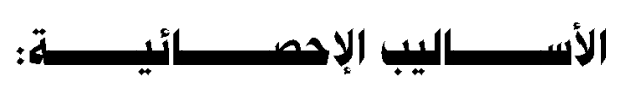

تم استخدام الأساليب الإحصائية التالية:

1- المتوسطات الحسابية والانحرافات المعياريـة على مستوى الفقرة للتعرف على مستوى الإسئ

ممارسة معلمات العلوم للتقويم البديل بمدينة المجمعة.

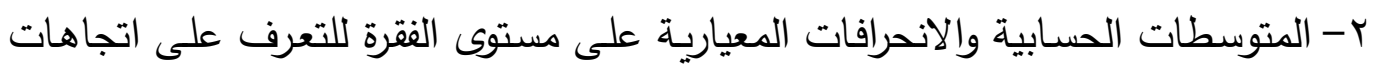

معلمات العلوم نحو التقويم البديل بمدينة المجمعة.

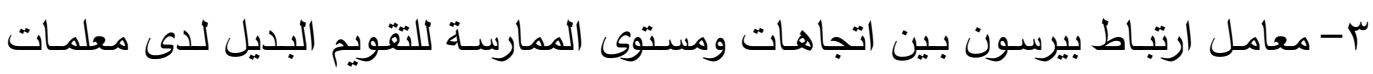

العلوم عينة الدراسة.

ع - معامل ارتباط بيرسون للتأكد من صدق الاتساق الداخلي لأداة الاستبانة.

ه- معامل ألفاكرونباخ للتأكد من ثبات أداة الاستبانة.

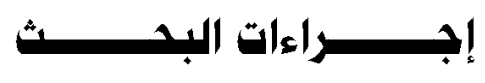

\section{مجتمع البحث وعينته}

تكوَّن مجتمع البحث من جميع معلمات العلوم لمراحل التعليم العام في مدينة المجمعة

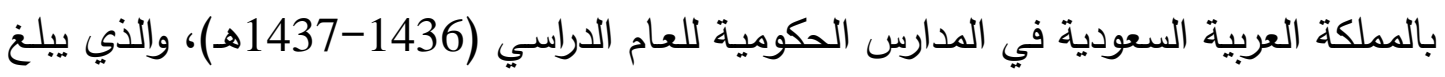

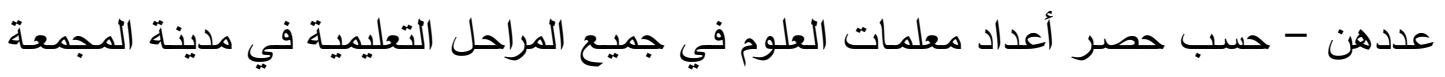
بإدارة التربية و التعليم بمحافظة المجمعة - (108) معلمة.

رأت الباحثة أن تكون عينة البحث هي مجتمعه؛ نظراً لمحدودية المجتمع، والبالغ عدده البهة

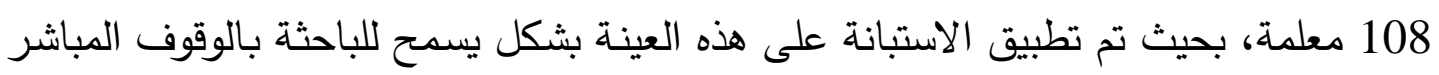
على واقع تصورات المعلمات حول التقويم البديل في مدينة المجمعة.

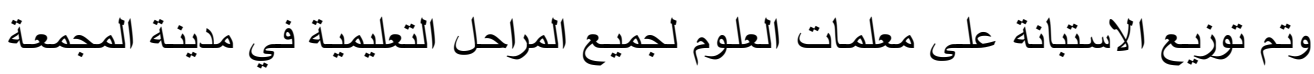

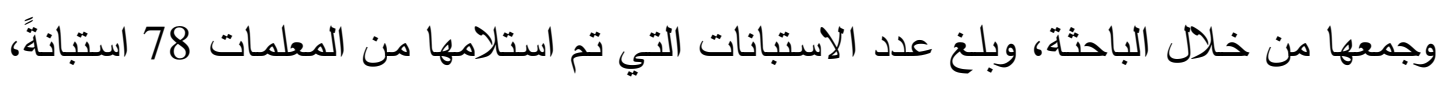

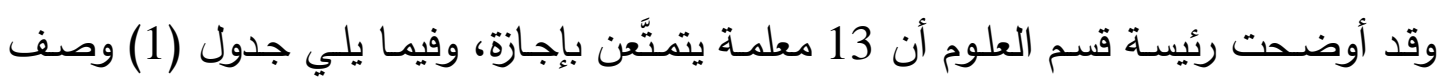
العينة من حيث التخصص، والخبرة في التدريس، والمرحلة التدريسية، ونوع المؤهل، والمؤهل العلمي. 


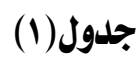

وصف العينة من حيث التخصص، والخبرة في التدريس، والمرحلة التدريسية، ونوع المؤهل، والمؤهل العلمي

\begin{tabular}{|c|c|c|c|c|c|}
\hline \multicolumn{3}{|c|}{ عينة البحث حسب المرحلة التدريسية } & \multicolumn{3}{|c|}{ عينة البحث حسب التخصص } \\
\hline النسبة (\%) & العدد & 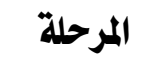 & النسبة (\%) & العلد & التخصص \\
\hline 14.1 & 11 & الابتدائية & 20.5 & 16 & كيمياء \\
\hline 14.1 & 11 & المتوسطة & 25.6 & 20 & فيزياء \\
\hline 71.8 & 56 & الثانوية & 47.4 & 37 & أحياء \\
\hline 100 & 78 & المجموع & 6.4 & 5 & علوم ورياضيات \\
\hline & & & 100 & 78 & المجموع \\
\hline \multicolumn{3}{|c|}{ عينة البحث حسب المؤهل العلمي } & \multicolumn{3}{|c|}{ عينة البحث حسب الخبرة في التدريس } \\
\hline النسبة (\%) & العلد العد & 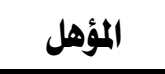 & النسبة (\%) & 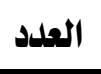 & الخبرة في التلدريس \\
\hline 6.4 & 5 & 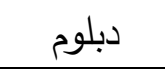 & 13 & 11 & أقل من ه سنوات \\
\hline 93.6 & 73 & بكالوريوس & 87 & 67 & أكثر من ه سنوات \\
\hline \multirow[t]{6}{*}{100} & 78 & المجموع & 100 & 78 & المجموع \\
\hline & & & \multicolumn{3}{|c|}{ عينة البحث حسب نوع المؤهل } \\
\hline & & & النسبة (\%) & العدد & 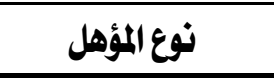 \\
\hline & & & 100 & 78 & ت تربوي \\
\hline & & & 0 & 0 & غير تربوي \\
\hline & & & 100 & 78 & المجموع \\
\hline
\end{tabular}

تم تطبيق مقابلة شبه مقننـة على عشر معلمات ضمن عينـة البحث، وتم اختيارهن

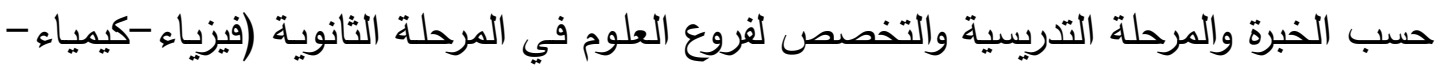
أحياء)؛ وذلك ليصبح أكثر تتوعاً لمستويات المعلمات في مجتمع البحث، بحيث تم اختيار معلمتين من المرحلة الابتدائية، ومعلمتين علوم للمرحلة المتوسطة، ومعلمتين تخصص فيزياء،

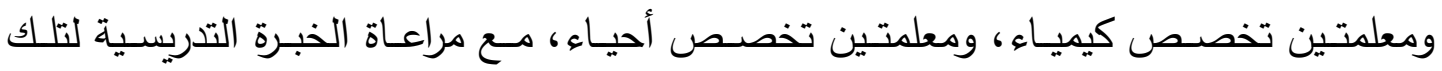

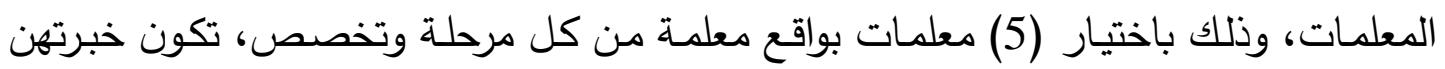

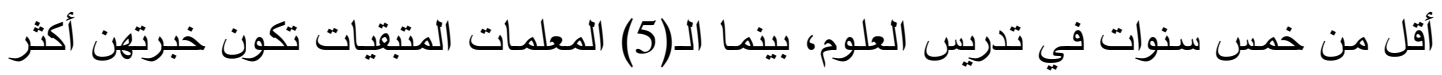
من خمس سنوات في تدريس العلوم. 


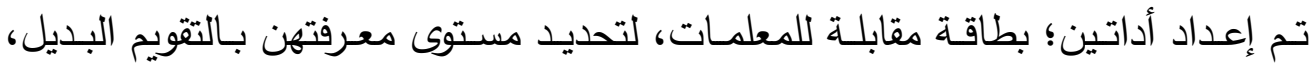

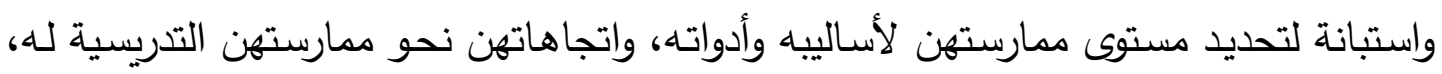

$$
\text { وهذا استعراض لإجراءات بناء الأداتين وصدقهما وثبات لإتبات الاستبانة: }
$$

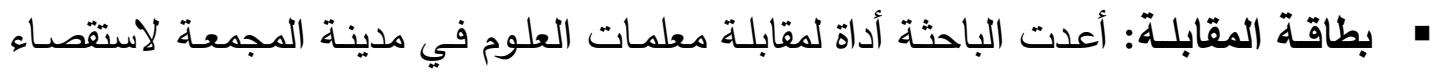

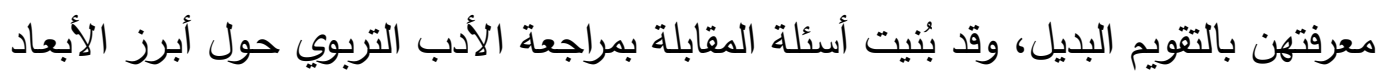

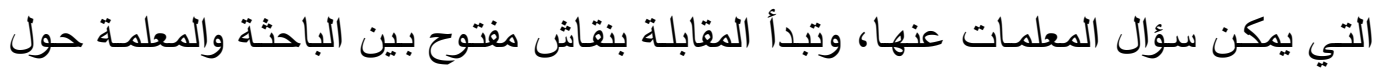

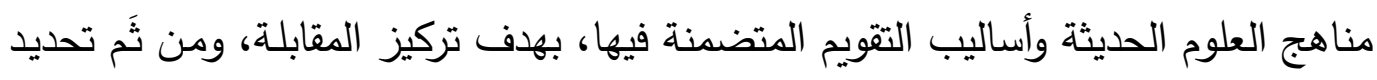

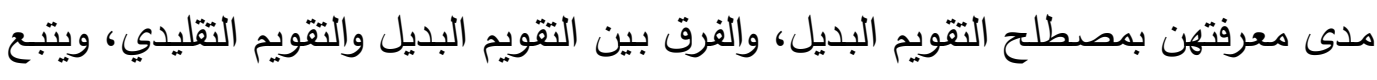

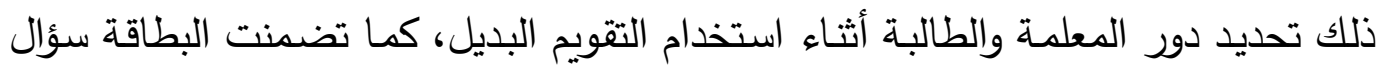
المعلمة عن أنواع أساليب التقويم البديل، وكيفية استخدامها في تقييم أداء الطالبات، وأخيرا

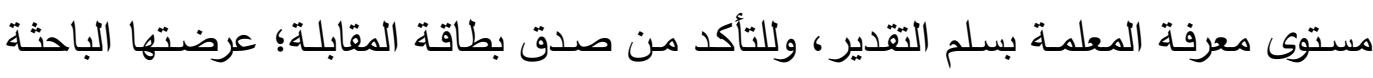

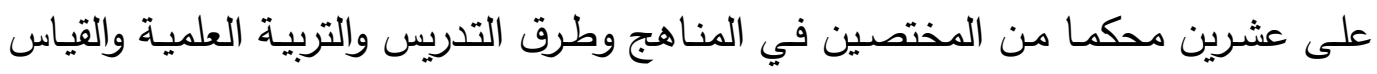

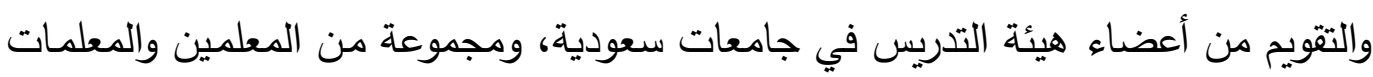

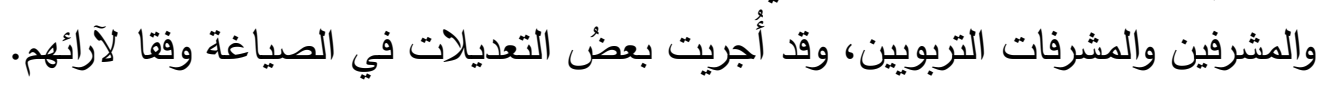

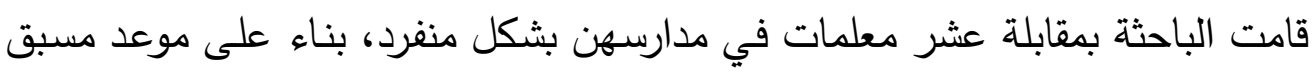

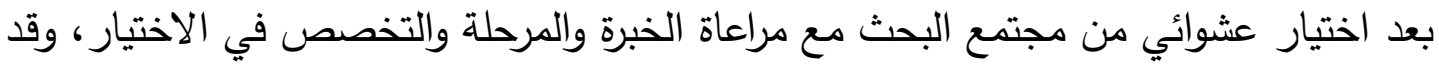

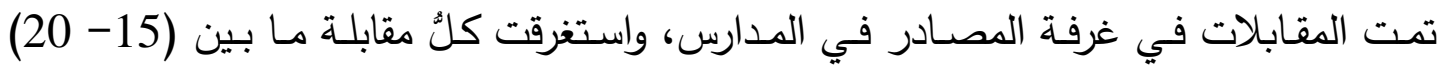
دقيقة، وتم تسجيل الملاحظات باستخدام جهاز تسجيل خاص، ثم تم تفريغها حرفياً على أوراق

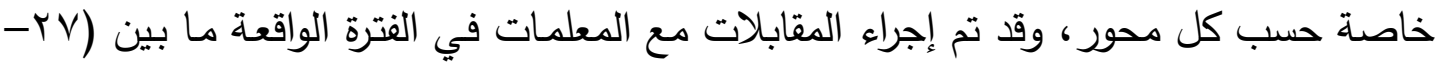

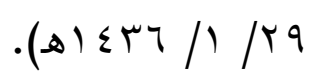

• أداة الاستبانة: تهدف إلى تحديد مستوى ممارسـة معلمات العلوم لأساليب التقويم البديل

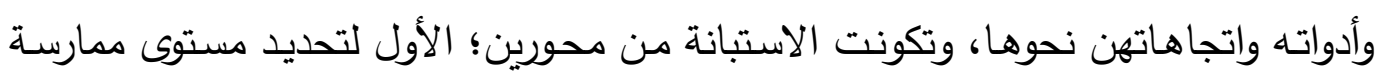

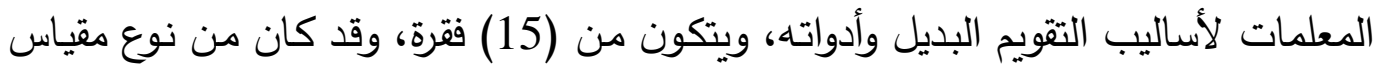

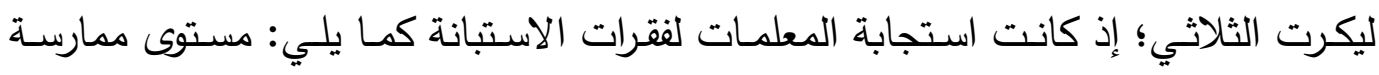

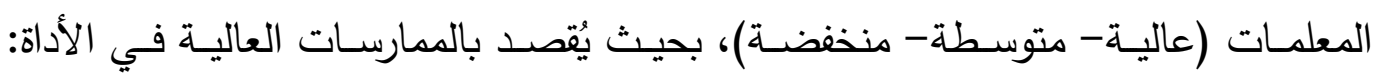

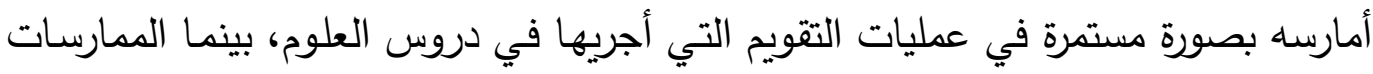

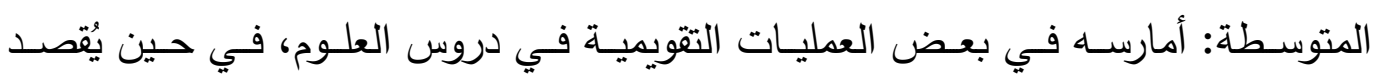


بالممارسات المنخفضة: نادرًا ما أقوم بممارسته في عمليات التقويم، بينما المحور الثاني من الاستبانة كان لتحديد اتجاهات المعلمات نحو ممارسة التقويم البديل، ويتكون من (15)

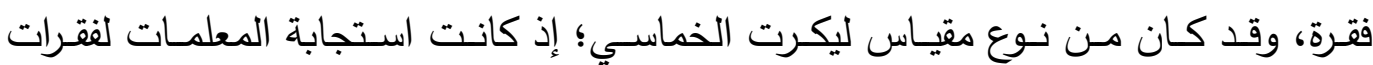
الاستبانة كما يلي:( موافق بشدة - موافق - محايد - غير موافق - غير موافق بشدة).

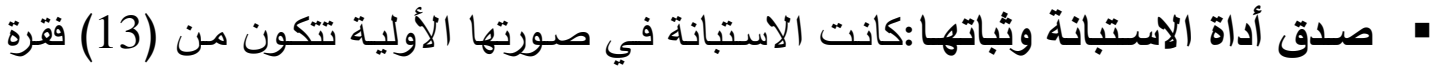
لمحور اتجاهات معلمات العلوم في مدينة المجمعة نحو ممارسة التقويم البديل، و(21) فقرة

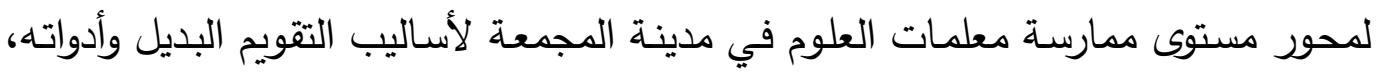
وتم التَحقق من صدق محتوى الاستبانة بعرضها على عشرين محكما من المختصين، وقد

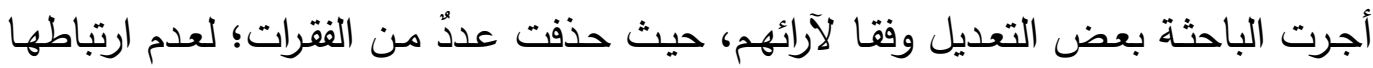

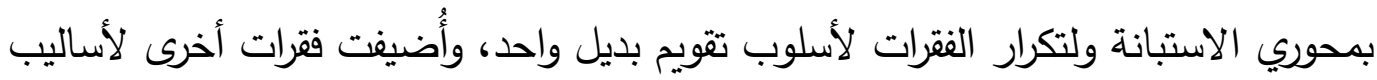

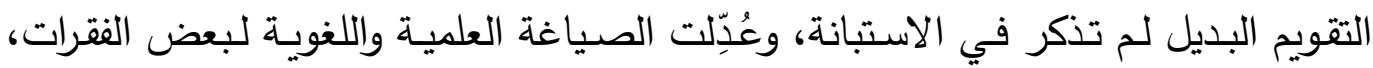
وتكوَّنت الاستبانة في صورتها النهائية من (15) فقرة لكل محور ، وحُسب معامل الاتساق

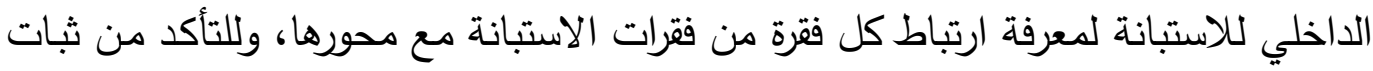
فقرات الاستبانة من خلال استخدام معامل ارتباط بيرسون، والجدول (2) يوضح نتيجة ذلك.

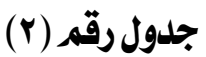

معاملات ارتباط بيرسون لعبارات الاستبانة بالدرجة الكلية للاستبيان

\begin{tabular}{|c|c|c|c|c|c|c|}
\hline معامل الارتباط & الفقرة & معامل الارتباط & الفقرة & معامل الارتباط & الفقرة & المحور \\
\hline$* * 0.58$ & 11 & $* * 0.55$ & 6 & $* * 0.52$ & 1 & \multirow{5}{*}{ التمارسة معلمات } \\
\hline ** 0.61 & 12 & $* * 0.43$ & 7 & $* * 0.66$ & 2 & \\
\hline$* * 0.69$ & 13 & $* * 0.65$ & 8 & $* * 0.60$ & 3 & \\
\hline$* * 0.67$ & 14 & $* * 0.46$ & 9 & $* * 0.55$ & 4 & \\
\hline$* * 0.64$ & 15 & $* * 0.35$ & 10 & $* * 0.70$ & 5 & \\
\hline$* * 0.57$ & 11 & $* * 0.61$ & 6 & $* * 0.59$ & 1 & \multirow{5}{*}{ التجاهات معلمات التقو ممارسة } \\
\hline$* * 0.52$ & 12 & $* * 0.57$ & 7 & $* * 0.53$ & 2 & \\
\hline$* * 0.68$ & 13 & $* * 0.61$ & 8 & $* * 0.63$ & 3 & \\
\hline$* * 0.61$ & 14 & $* * 0.71$ & 9 & $* * 0.54$ & 4 & \\
\hline$* * 0.57$ & 15 & $* * 0.57$ & 10 & $* * 0.64$ & 5 & \\
\hline
\end{tabular}


يتضح من الجدول(2) أن قيم معامل ارتباط كل فقرة من الفقرات مـع محورها موجبـة

ودالة إحصـائياً عند مستوى الدلالـة (0.01) أو(0.05) فأقل؛ مما يشير إلى أن جميع فقرات

الاستبانة تتمتع بدرجة اتساق داخلي مرتفعة جداً، ويؤكد قوة الارتباط الداخلي بين جميع فقرات

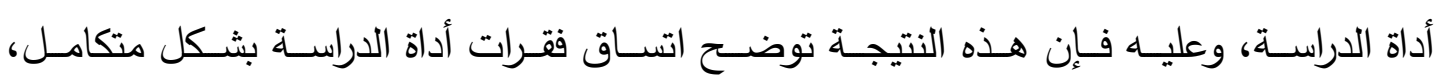
وصلاحيتها للتطبيق الميداني.

كمـا حُسـب معامـل الثبـات حسـب محـوري الاسـتبانة باسـتخدام معادلـة اختبـار معامـل ألفاكرونباخ لمحور الأداة الأول الذي بلغ (0.86)، وللمحور الثاني الذي بلغ (0.87)، في حين كان للأداة ككل (0.91)، وهو معامل ثبات مرتفع ومقبول تربويًا؛ إذ يشير إلى صلاحية الأداة لتحقيق أهداف الدراسة الحالية، ويوضـح الجدول (3) معامل ألفا كرونباخ لمحوري أداة الدراسـة وللأداة ككل.

\section{جدول رقيم (r)}

معامل ألفاكرونباخ لمحوري أداة الاستبانة وللاستبانة ككل

\begin{tabular}{|c|c|c|c|}
\hline كعامل ألثا & العبارات & المحور & هـ \\
\hline 0.86 & 15 & ممارسة معلمات العلوم لأساليب التقويم البديل وأدواته & 1 \\
\hline 0.87 & 15 & اتجاهات معلمات العلوم نحو ممارسة التقويم البديل & 2 \\
\hline 0.91 & 30 & الكلي & \\
\hline
\end{tabular}

تحليل البيانات النومية :

قامت الباحثة بإجراء مقابلـة شبه مقنــة مـع عشر معلمـات للعلوم في مدينة المجمعـة

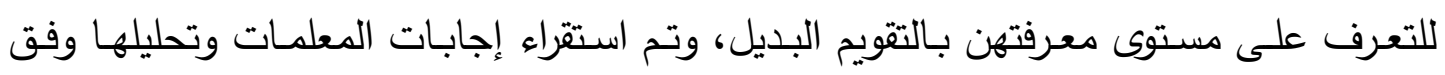
المنهج النوعي، وتركيز معرفتهن وفق أربع أفكار رئيسة، وهي: تعريف التقويم البديل، ودور المعلمة والطالبة أثناء استخدامه، أنواع أساليب التقويم البديل وكيفيـة استخدامها، ومعرفة سلم التقدير ، وكانت استجابات العينة كالتالي:

\section{أولاً: تعريف النقوبيم البديل}

أجابت ست معلمات بأنهن لم يسمعن بمصطلح التقويم البديل، في حين أربع معلمات

أجبن أنهن سمعن به، وعند سؤالهن عن المقصود بمصطلح التقويم البديل قدَّمت ثلاث معلمات 
إجابات غير دقيقة، على سبيل المثال كانت إجابة المعلمة(4): "التعرف على مشاكل الطالبات

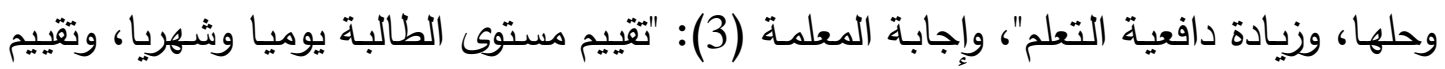

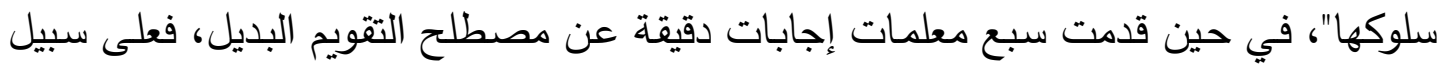

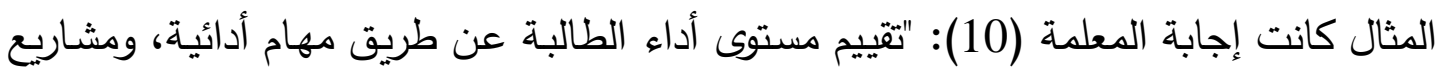

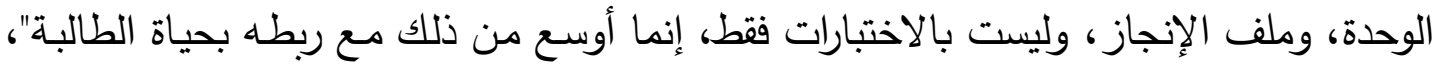

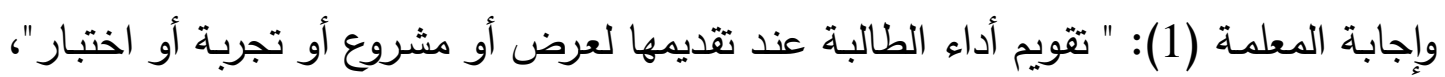

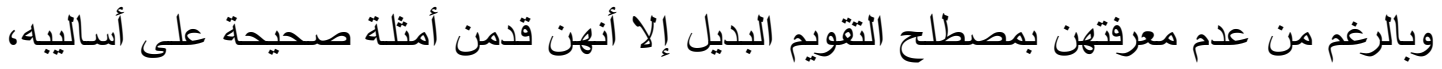

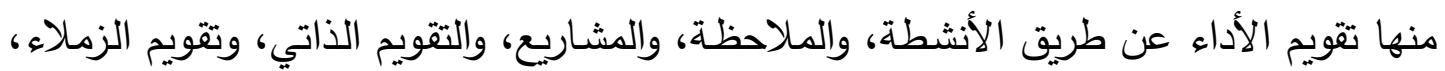
واستطاعت تسع معلمات التقريق بين التقويم البديل والتقويم التقليدي بشكل دقيق، وذلك عندما ذكرن أن التقويم التقليدي يركز على حفظ وتذكر المعلومات بالتلقين، والطالبة تكون مستقبلة

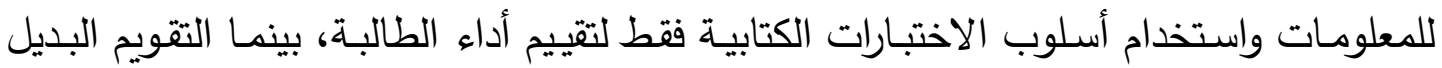
أفضل من التقويم التقليدي؛ لأنه يقلل من رهبة الاختبار، وينمي مهارات التنكير العليا، ويتم

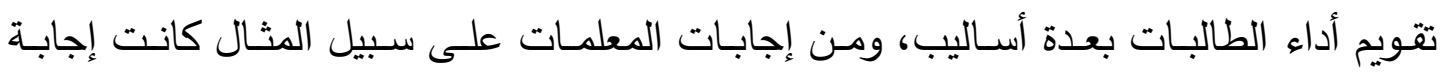

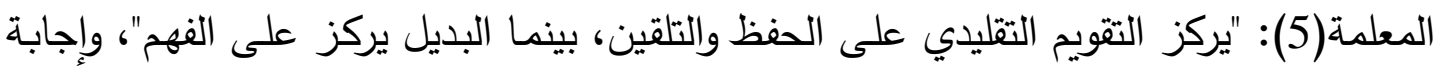

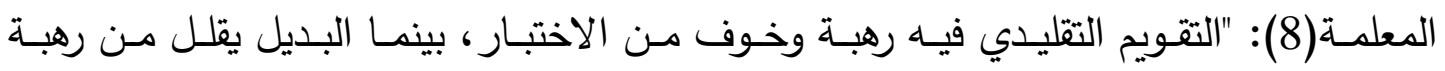
الاختبار"، وإجابة المعلمة(2): "التقويم التقليدي فيه ملل، وتؤديه الطالبة بمفردها، بينما البديل

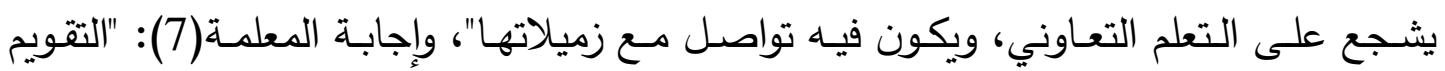

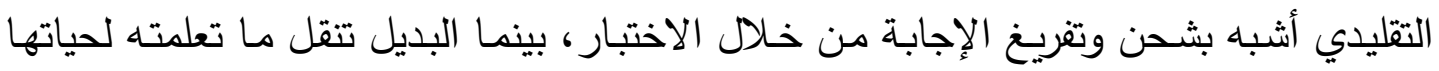
ومجتمعها"، في حين معلمة واحدة للمرحلة المتوسطة لا ترى وجود فرق بين بين التقويم البديل

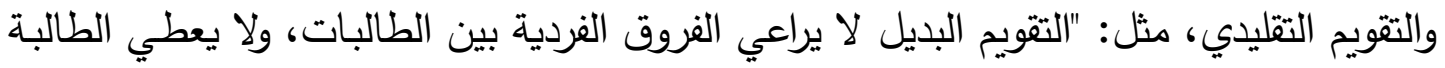

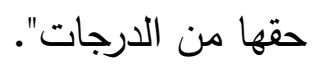

\section{ثانياً: دور المعلمة ودور الطالبة أثناء استنفدام النقويمم البديل}

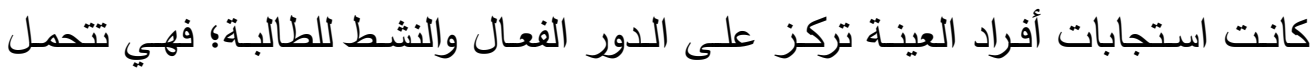

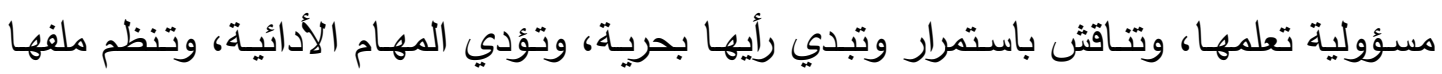

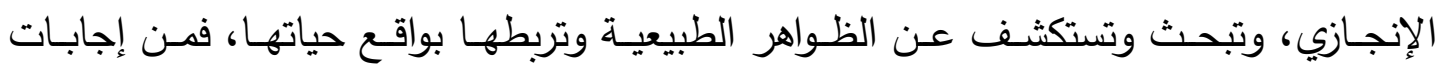
المعلمات - على سبيل المثال - كانت إجابة المعلمة(1): "التركيز أكثر على الطالبة، بحيث وتيث 
تبحث الطالبة عن المعلومات في مصسادر خارج الكتاب المدرسي"، وإجابة المعلمة (6) : "إن

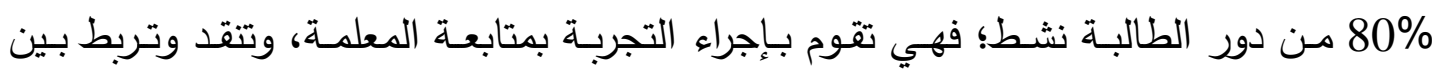
المعلومات، وتستتنج".

في حين رأت أفراد العينـة أن دور المعلمـة يكون في توجيـه الطالبـات، ومتابعـة أداء وتهاء الطالبات، وتيسير مهمة أداء الطالبة، وتشرف عليها، ومن إجاباتهن - على سلى سبيل المثال -

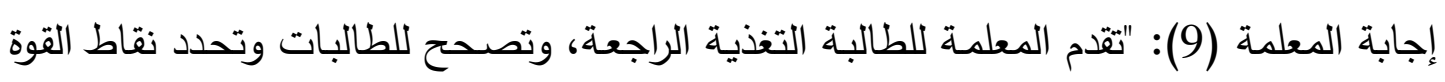

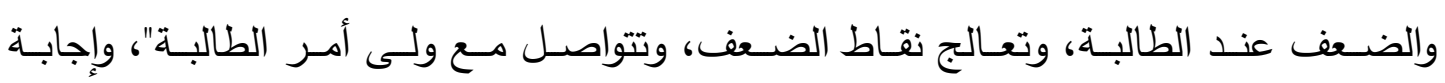

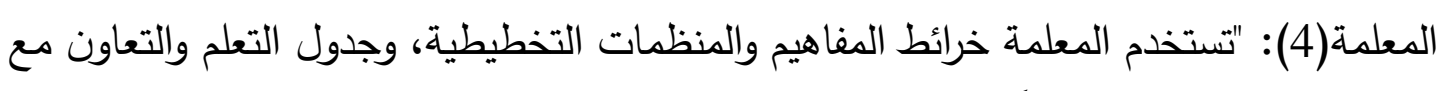
ولي الأمر ، بحيث يكون مطلَّعا على نتائج تحصيل ابنته".

\section{ثالثاً: أنواع أساليب النتقويم البديل وكيفية استنفامها}

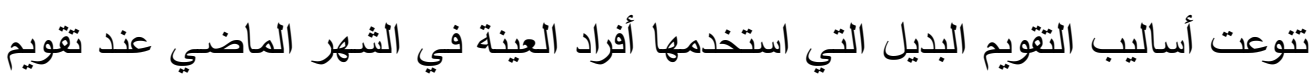
أداء الطالبـات، ومـن إجابـات المعلمـات - على سبيل المثنال - كانـت إجابـة المعلمـة (1):

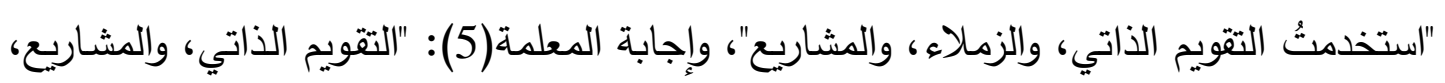

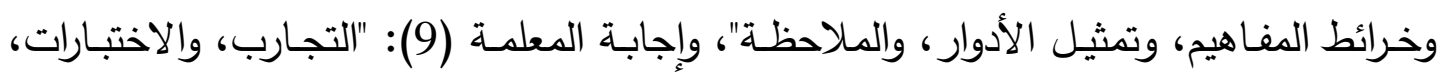

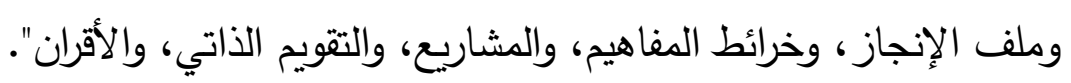

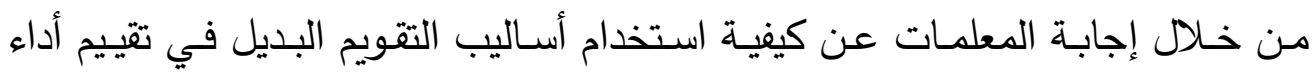

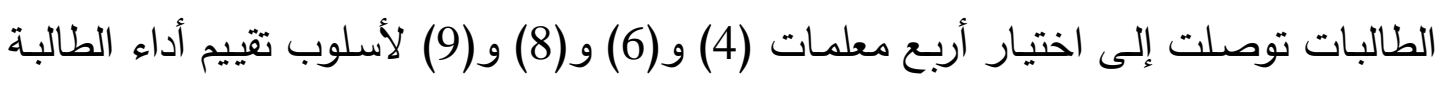

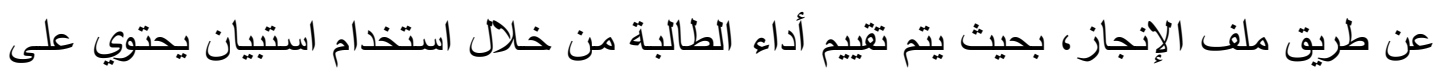

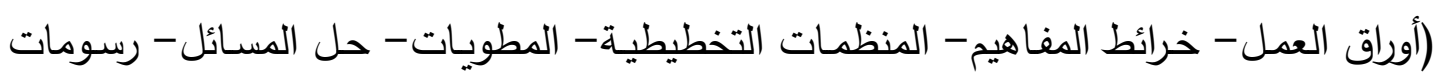

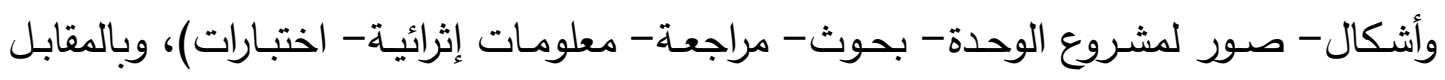
يوجد درجات أو تقديرات، بينما ذكرت ثلاث معلمات (1) و و(5) و(7) أسلوب تقييم أداء الطالبة

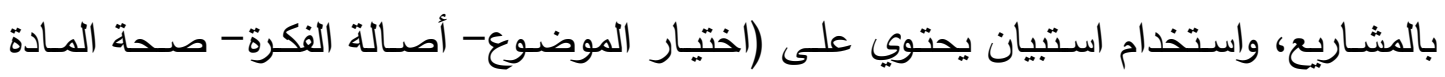

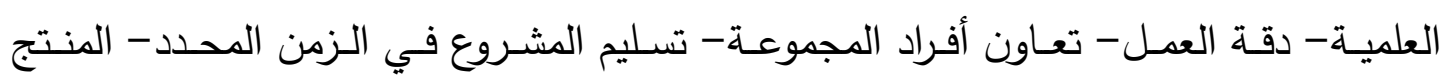

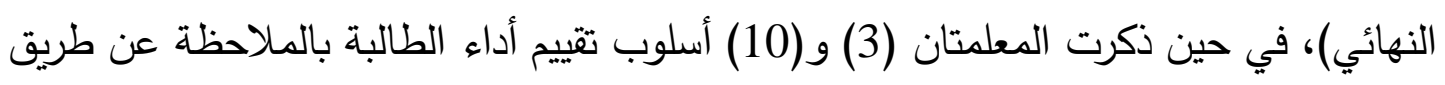

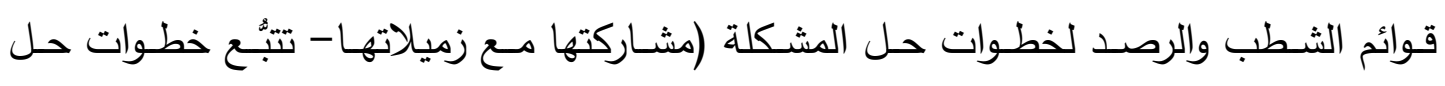

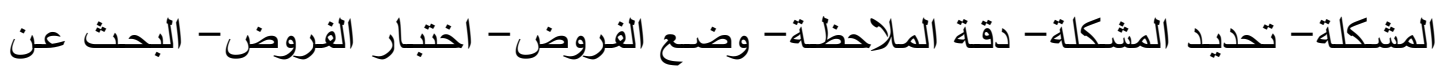


صـحة الفروض- قدرتها على الاستتناج الصحيح- تعديم النتيجة)، وبالمقابل توجد قائهـة

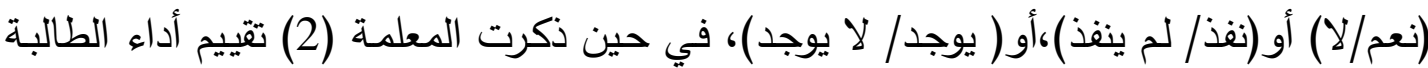
عن طريق خريطة المفاهيم عن طريق سلم التقدير، ويوجد فيه (معرفة المفاهيم الكبرى- معرفة

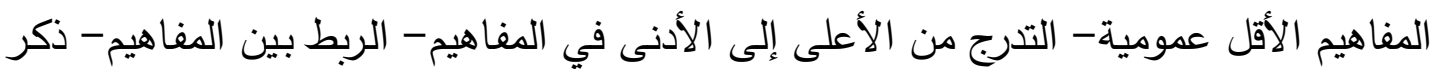

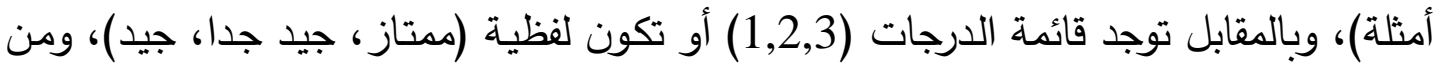
إجابات أفراد العينة يتضح معرفتهن لأساليب التقويم البديل، وممارستهن التدريسية الصحيحة

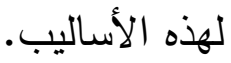

\section{رابعاً: معرفة سلم النققدير التهابر}

كانت استجابات أفراد العينة أن ثماني معلمات لا يعرفن مصطلح "سلم التقدير" ويطلقنَ عليه مسـى الاستبيان، لكنهن قدمن أمثلة صحيحة على استخدام سلم التقدير من خـلال الأنشطة العملية، مثل إجابة المعلمة(10): "وضع عبارات في جدول؛ كقدرتها على استخدام المجهر - تحديد نوع الخلية من شريحة المجهر - معرفة مكونات الخلية- دقة رسم ما شاهدته

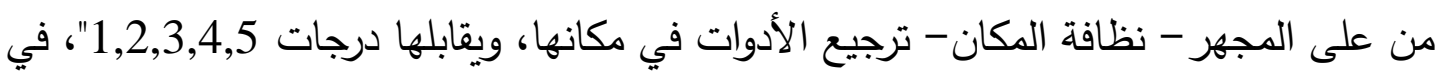
حين معلمتان أجابتا أنهما تعرفان مصطلح (سلم التقدير)، وقدمتا إجابات دقيقة، مثل: "جدول يتكون من بنود ونقاط لمحتوى تجربـة أو ملف إنجاز أو مشروع، وتوجد في المقابل تقديرات

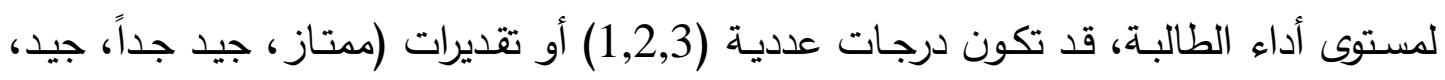
يحتاج إلى مساعدة) أو (متمكن، ماهر ، متقدم، مبتدئ)". وبذلك نتوصل إلى قصور معلمات العلوم في مدينة المجمعة في معرفة مصطلح التقويم البديل، ومصطلح سلم التقدير ، ويؤيد ذلك دراسة العصفور (2006م) التي أظهرت أن امتلاك معلمي ومعلمات المرحلة المتوسطة لهفاهيم ومصطلحات التقويم التربوي والبديل كانت ضعيفة، وبالرغم من عدم معرفة المعلمات بمصطلح التقويم البديل إلا أنهن استطعن التثريق بين التقويم البديل والتقويم التقليدي بشكل دقيق، ومعرفة دور المعلمة ودور الطالبة بشكل جيد، وهذا يؤيد دراسة الحمد (2004م)، واللبودي (2005م) اللتين أظهرتا أهمية امتلاك المعلم لمهارات توظيف دوريف التقويم البديل، كما اتضح أن معلمات يمارسن سلم التقدير بشكل جيد. 


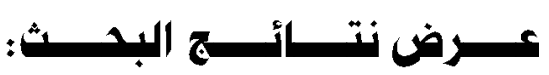

\section{أولاً : الإجابة على السؤال الأول : ما مستوى معرفة معلمـات العلوم في مدينـة المجمعة بـالتقويه}

\section{البلديل؟}

قامت الباحثة بالإجابة على السؤال من واقع البيانات النوعية لأداة الدقابلة، وتم التركيز

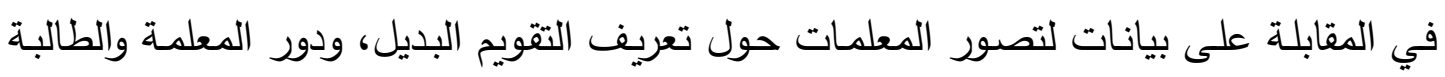
في استخدامه، وأنواع أساليبه وكيفية استخدامها، ومعرفة سلم التقدير .

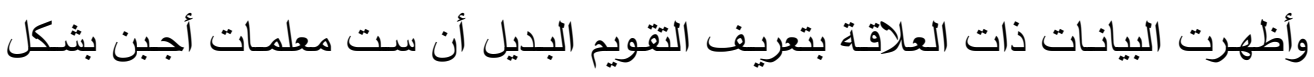

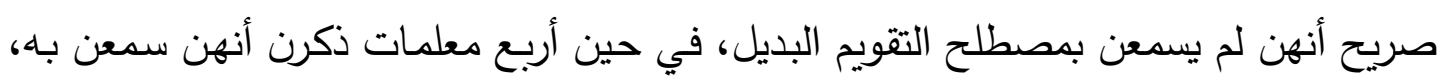

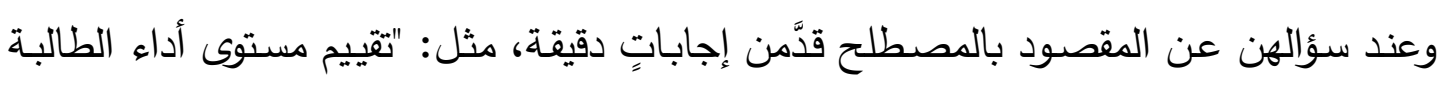

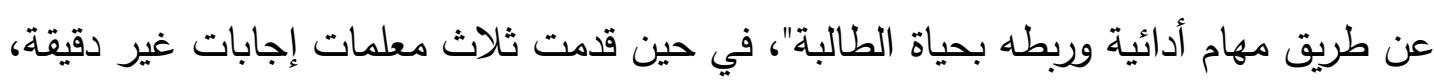

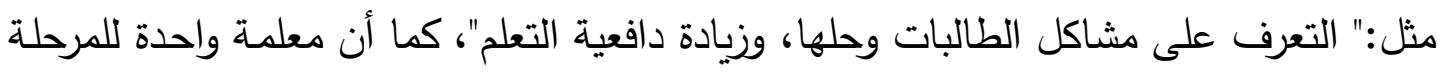

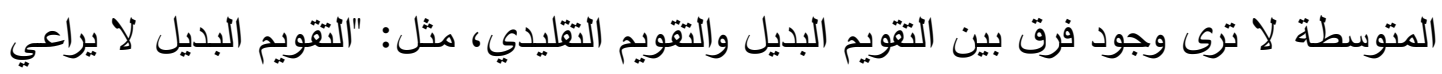

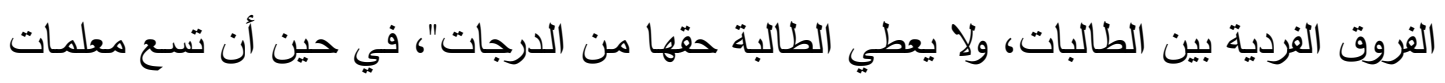

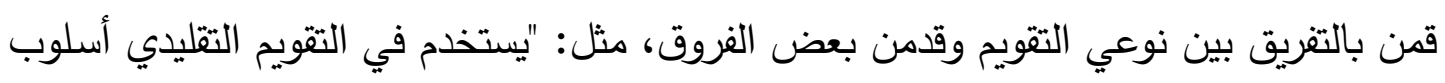

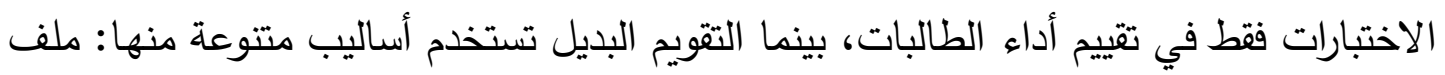

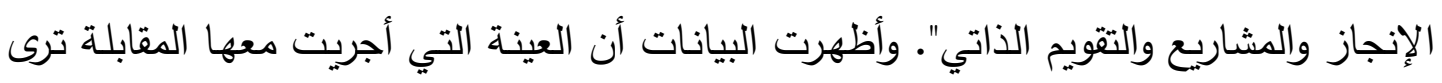

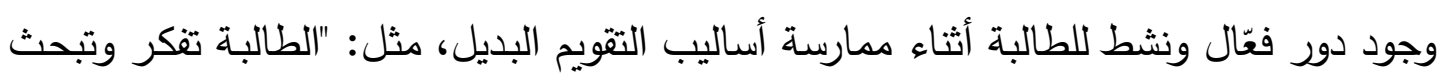

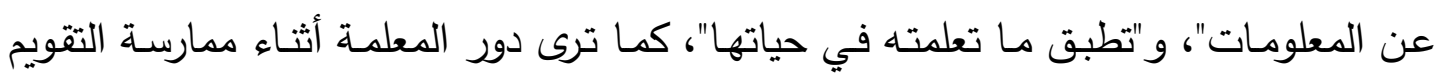

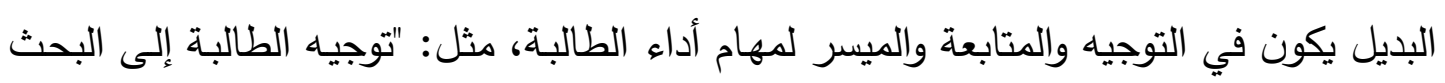
والاستقصاء والتتكير الناقد ومتابعة أدائها".

كما أظهرت البيانات أن العينـة تستخدم أسـاليب متتوعة من التقائه التقويم البديل من خلال

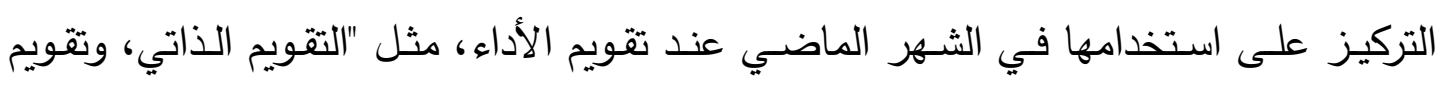

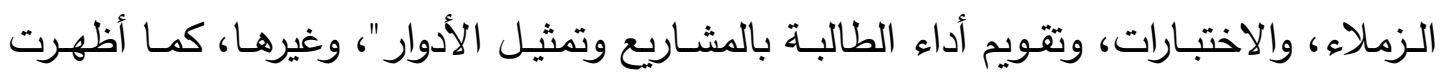

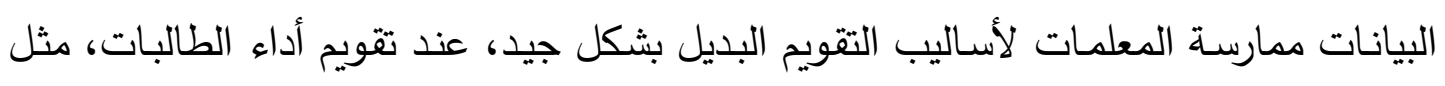

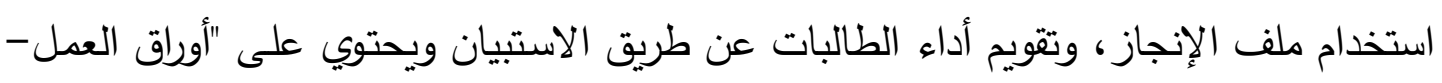

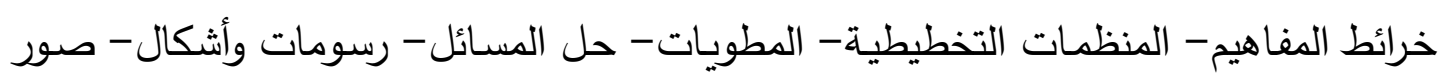


المشروع الوحدة- بحوث- مراجعة- معلومات إثرائية- اختبارات"، وأسلوب تقييم أداء الطالبة

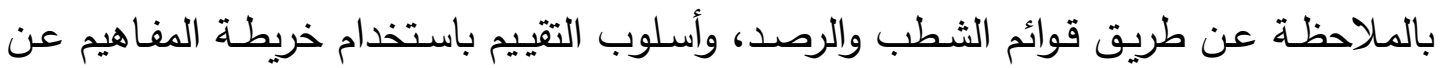

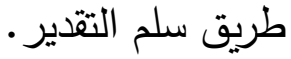
وأظهـرت البيانـات ذات العلاقـة بمعرفـة سـلم التقدير أن ثماني معلمـات أجبن بشكل

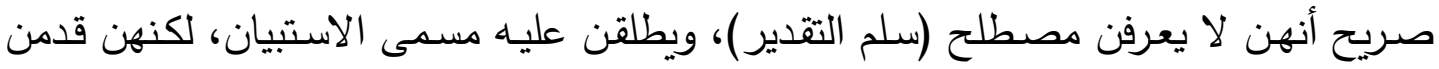

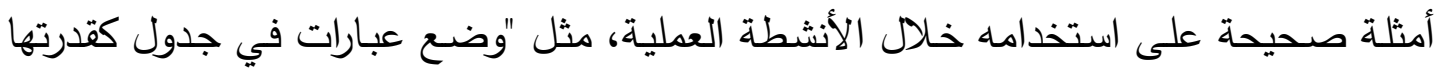
على استخدام المجهر - تحديد نوع الخلية من شريحة الهجر - التعرف على مكونات الخلية-

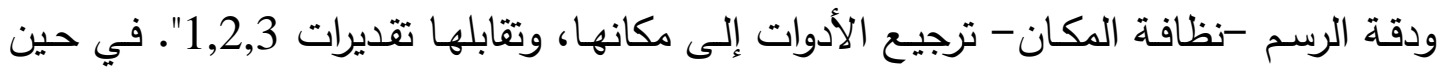

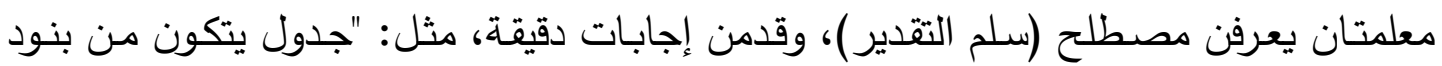

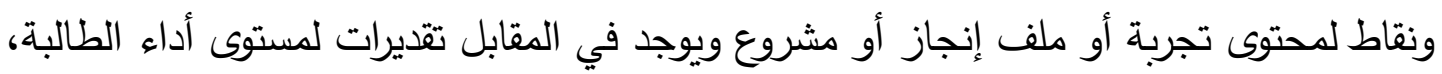
قد تكون درجات عددية أو تقديرات".

\section{ثانياً : الإجابة على السؤال الثاني : ما مستوى ممارسة معلمات العلوم في ملينة المجمعة لأساليب}

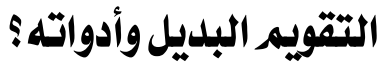

للإجابة عن سؤال البحث الثاني تم تطبيق استبانة للتعرف على أساليب التقويم البديل

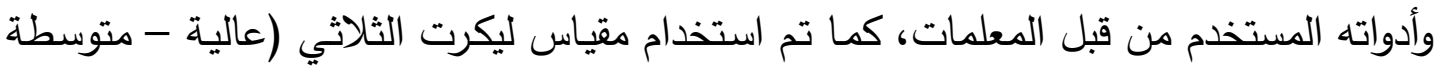
- منخفضة) لتحديد مستوى ممارسة كل فقرة من فقرات الاستبانة, وتم تمثيله عددياً كما يلي:

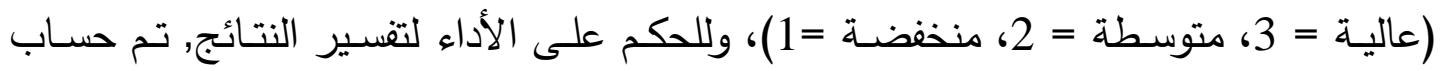
طول فئة معيار الحكم على النتائج من خلال تصنيف الإجابات إلى ثلاثة مستويات متساوية

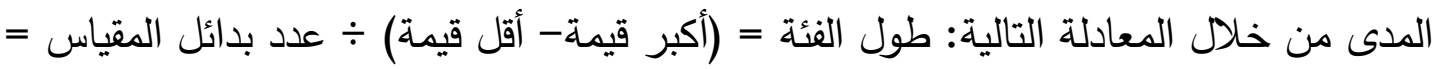

$$
0.67=3 \div(1-3)
$$

لنحصل على مدى المتوسطات التالية لكل وصف أو بديل:

\begin{tabular}{|c|c|c|c|}
\hline منخفضة & متوسطة & عالية & مستوى الممارسة \\
\hline من 1 - 1.67 & أعلى من 1.67- 2.34 & أعلى من 2.34 - 3 & مدى المتوسطات \\
\hline
\end{tabular}

كما تم حساب المتوسطات الحسابية والانحرافات المعيارية لاستجابات أفراد العينة على فقرات الاستبانة، والجدول (4) يوضح ذلك: 


\section{جدول رقم (₹)}

المتوسطات الحسابية والانحرافات المعيارية لاستجابات أفراد العينة حول ممارسة التقويم البديل

\begin{tabular}{|c|c|c|c|c|}
\hline مستوى & الانحراف & الحسابي & 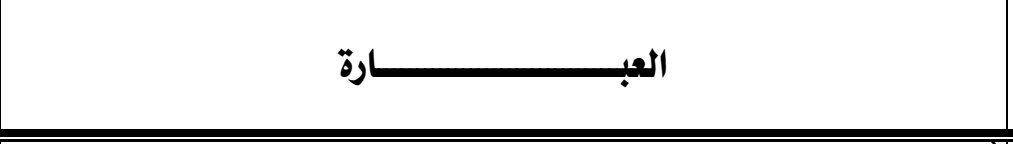 & هـ \\
\hline عالية & 0.51 & 2.78 & 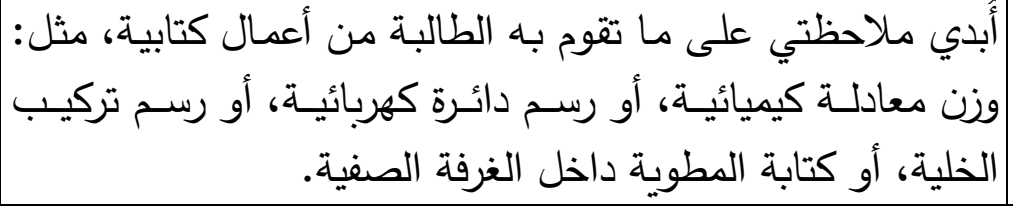 & 1 \\
\hline عالية & 0.61 & 2.64 & أركز على اكتساب مهارة القدرة على تبرير الإجابة لدى الطالبة. & r \\
\hline عالية & 0.59 & 2.63 & أستخدم أسلوب الأسئلة السابرة خلال الدرس. & $r$ \\
\hline 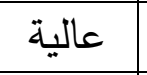 & 0.57 & 2,60 & أطلب من الطالبات بناء خرائط مفاهيم في العلوم. & $\varepsilon$ \\
\hline عالية & 0.63 & 2,60 & مأتيح للطالبة تقويم تعلمها ذاتياً باكتشاف أخطائها حين تحل مشكلة & 0 \\
\hline عالية & 0.66 & 2.55 & |ُٔشجّع الطالبة على استخدام الأسئلة التأملية. & 7 \\
\hline عالية & 0.68 & 2.54 & أثناء الدوّم أداء الطالبـة عن طريق عرض إنتاجها من نشـاطات عملية & $\vee$ \\
\hline عالية & 0.64 & 2.50 & وأُشجّع الطالبة على تقويم الأقران لأنشطة زميلاتها داخل الصف & $\wedge$ \\
\hline 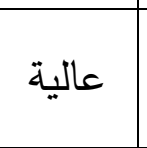 & 0.66 & 2.50 & أُكلّف الطالبة بأداء مهام عمليـة محددة لتوضيح المعرفة العلميـة & 9 \\
\hline عالية & 0.72 & 2.46 & أُ أُحدّد مسبقاً محكات الحكم على محتويات ملف الإنجاز بمشاركة & $1 \cdot$ \\
\hline 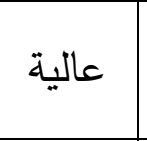 & 0.75 & 2.46 & أسـتخدم ملفـات الإنجـاز للمقارنــة بين تحصسيل وتقدم الطالبـة في & 11 \\
\hline عالية & 0.77 & 2.42 & أُشجع الطالبة على استخدام مشاريع الوحدة أو الفصل في تعليم & Ir \\
\hline عالية & 0.63 & 2.41 & أُشجّع الطالبة على استخدام التقديرات الذاتية لتحديد مستوى تقدم & M \\
\hline 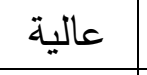 & 0.60 & 2.36 & |أُصمم أدوات متتوعة للتقويم البديل في مادة العلوم. & $1 \varepsilon$ \\
\hline متوسطة & 0.76 & 2.16 & |أقَّمّم أداء الطالبة باستخدام أسلوب لعب الأدوار • & 10 \\
\hline 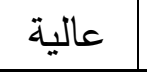 & 0.65 & 2.51 & المحور الأول ككل & 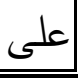 \\
\hline
\end{tabular}


ويتضح من الجدول(4) أن متوسط الدرجات لاستجابات أفراد العينة على الدحور الأول

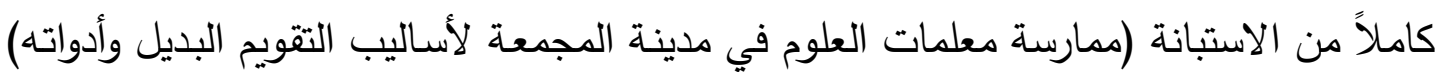

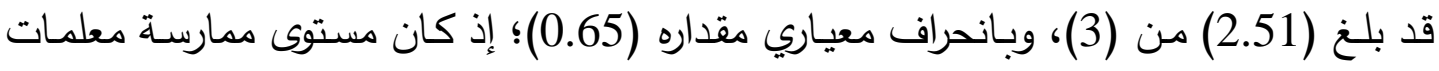

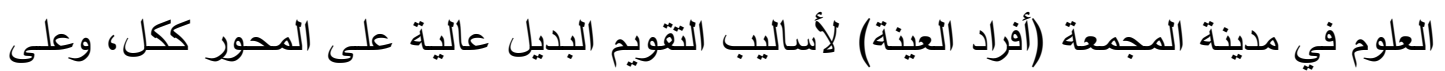

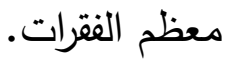

\section{ثالثًا : الإجابة على السؤال الثالث: ما اتجاهات معلمات العلوم في ملدينـة المجمعة نحو ممارسة}

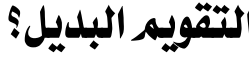

للإجابة عن السؤال تم تطبيق استبانة للتعرف على اتجاهات المعلمات نحو ممارسـة

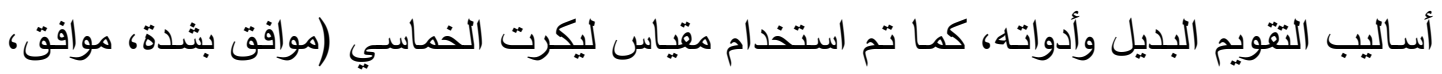
محايد، غير موافق، غير موافق بثدة) لتحديد مستوى ممارسة كل فقرة من فقرات الاستبانة, وتم

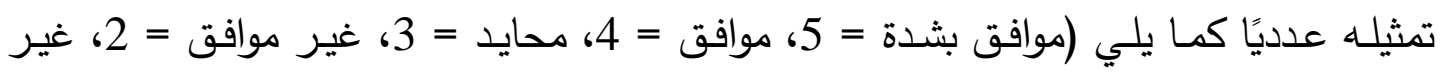
موافق بشدة =1)، وتم عكس المقياس في الفقرات السلبية فقرة (14) و (15) بحيث تكون

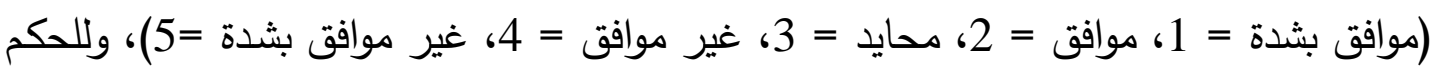

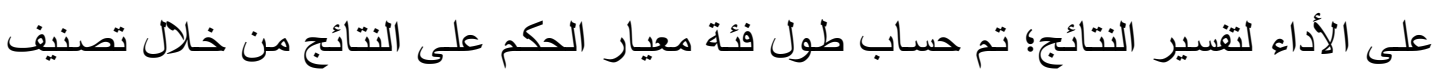

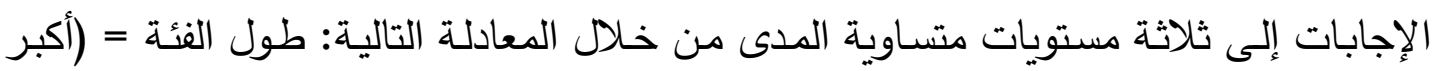

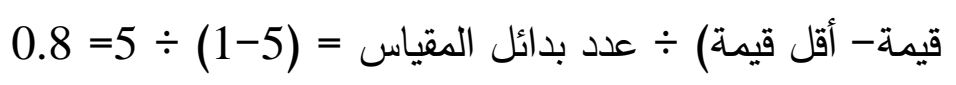

لنحصل على مدى المتوسطات التالية لكل وصف أو بديل:

\begin{tabular}{|c|c|c|c|c|c|}
\hline غير موافق & غير موقق & محايد & مواقق & مواقق بشلة & مستوى \\
\hline من & أعلى من & أعلى من & أعلى من & أعلى من & مدى \\
\hline $1.8-1$ & $2.60-1.80$ & $3,40-2.60$ & $4.20-3,40$ & $5-4.20$ & المتوسطات \\
\hline
\end{tabular}

كما تم حساب المتوسطات الحسابية والانحرافات المعيارية لاستجابات أفراد العينة على فقرات الاستبانة، والجدول (5) يوضح ذلك: 


\section{جلدول رقم (0)}

\section{المتوسطات الحسابية والانحرافات المعيارية لاستجابات أفراد العينة}

\section{حول وجهة نظر المعلمات نحو ممارسة التقويد البليل}

\begin{tabular}{|c|c|c|c|}
\hline الانحراف & الحسابي & من وجهة نظري، إن التقويم البديل: & A \\
\hline 0.66 & 4.56 & يستند إلى المشاركة الفاعلة للطالبة في عمليتي تعليم العلوم وتعلمها. & 1 \\
\hline 0.71 & 4.56 & يُركز على العمل التعاوني في تعليم العلوم وتعلمها. & 2 \\
\hline 0.66 & 4.50 & العُلوم لدى المعلمـة بمعلومـات مستمرة حـول نواحي القوة والضـف فلى في تعليم & 3 \\
\hline 0.62 & 4.49 & يُشهم في تهيئة الطالبة للاعتماد على نفسها في تعليم العلوم. & 4 \\
\hline 0.70 & 4.47 & يُساعد المعلمة على اختيار استراتيجيات تدريس العلوم الملائمة. & 5 \\
\hline 0.70 & 4.45 & يُسسهم في تتمية مهارات التفكير العليا لدى الطالبة. & 6 \\
\hline 0.78 & 4.41 & يُشُجع الطالبة على الاستقصاء خارج كتب العلوم المدرسية. & 7 \\
\hline 0.90 & 4.39 & يُشجع الطالبة على التفكير التأملي. ــ & 8 \\
\hline 0.70 & 4.33 & يَضْن جودة تعليم العلوم ونواتج تعلمها. & 9 \\
\hline 0.78 & 4.31 & يُكگّن ولي أمر الطالبة من متابعة مدى تقدم التحصيل الدراسي لابنته. & 10 \\
\hline 0.78 & 4.29 & يُعزز قدرة الطالبة على التقويم الذاتي. & 11 \\
\hline 0.79 & 4.29 & يُقدم نتائج دقيقة عن مستوى تعلم كل طالبة لمادة العلوم. & 12 \\
\hline 0.96 & 4.22 & يُسهم في تطوّر المهارات الحياتية للطالبة. & 13 \\
\hline 1.12 & 3.44 & لا يساعد على مراعاة الفروق الفردية بين الطالبات. & 14 \\
\hline 1.21 & 3.24 & يعطي نتائج أقل دقة حول تعلم الطالبة من التقويم التقليدي. & 15 \\
\hline 0.81 & 4.26 & المحور الثاني ككل & على \\
\hline
\end{tabular}

ويتضح من الجدول(5) أن متوسط الدرجات العام لاستجابات أفراد العينة على الدحور

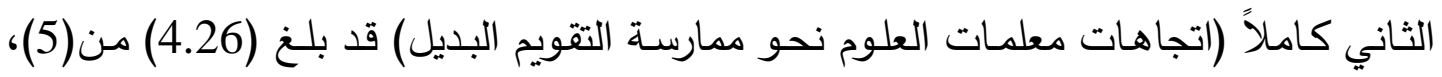

وبانحراف معياري مقداره(0.81)، وبذلك تكون اتجاهات معلمات العلوم عالية جداً نحو ممارسة

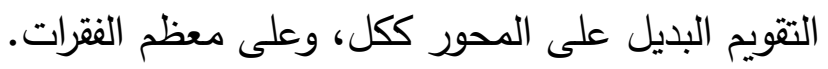




\section{رابعًا : الإجابـة على السؤال الرابـع : مـا مستوى ارتبـاط اتجاهـات معلمـات العلور نحو ممارسة}

\section{التقويد البلديل وممارستهن التدريسية في ملينة المجمعة؟}

للتعرف على مدى وجود علاقة ارتباطية ذات دلالة إحصائية عند مستوى م ج 0.01

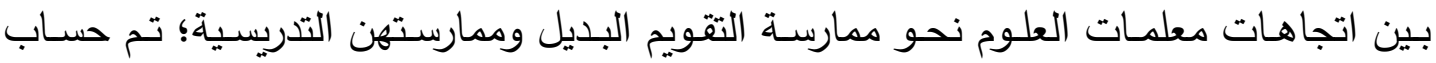
معامل ارتباط بيرسون لعدد (78) معلمة, واتضح أن هنالك معامل ارتباط موجبًا قيمته بـاته مما يدل على وجود علاقة ارتباطية طردية متوسطة بين اتجاهات معلمات العلوم نحو ممارسة

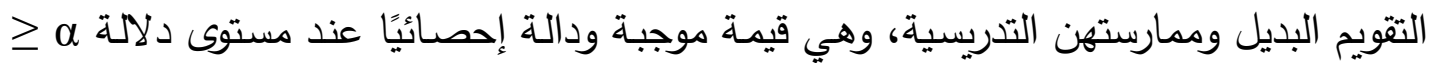

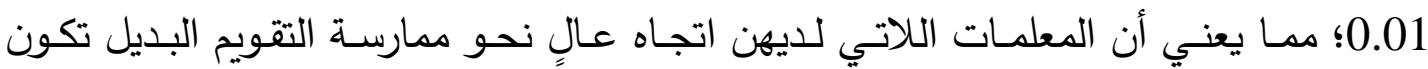
ممارستهن لأساليبه عالية.

\section{مناقشة النتائج وتفسيرها}

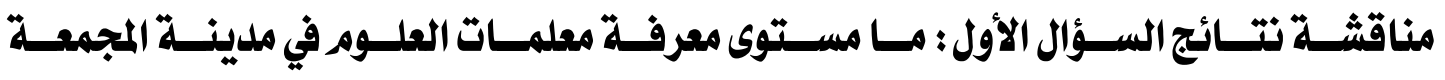

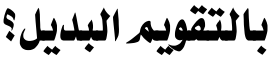

يتضـح من النتائج التي أظهرتها البيانات ذات العلاقة بتعريف التقويم البديل أن أكثر

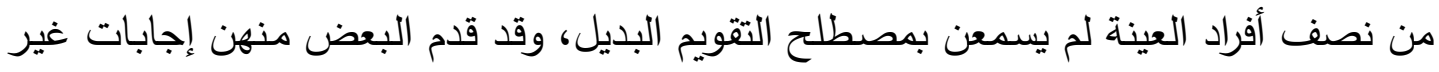

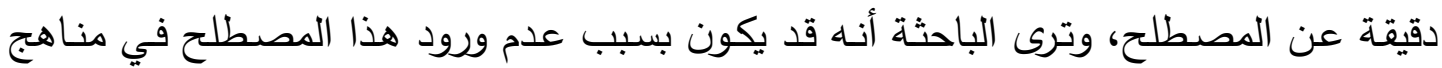
العلوم الطبيعية، وعدم وجود دورات تدريبية عن التقويم البديل، وبـالرغم من عدم معرفتهن

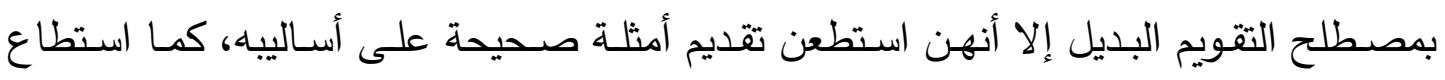

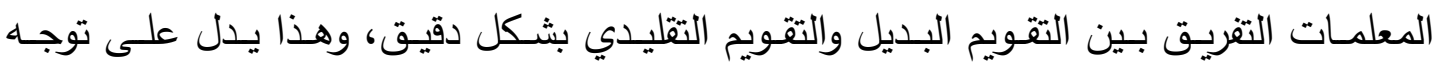

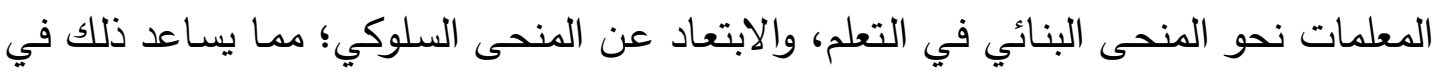
زيادة التحصيل العلمي وبناء المعرفة لتكون أكثر بقاءً في ذهن الطالبة، وتؤيد إجابتهن دراسة كلٍ من تساجاري (Tsagari, 2004)، وزيتون(2007) التي أظهرت أن التقويم البديل يمكِّن

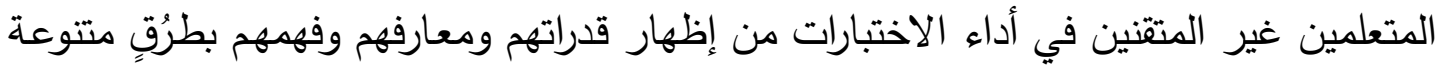

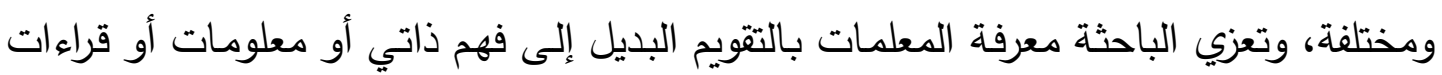
شخصية سابقة، وتدريس مناهج العلوم الحديثة، وممارسة أساليب التقويم البديل المتضمنة فئها، دانيا،

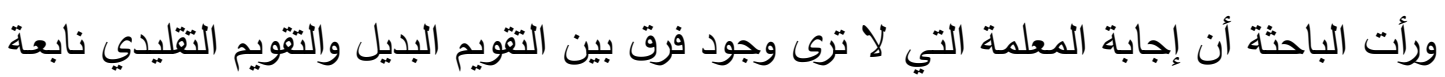


عن سببين؛ أولهما: بالرغم من ممارسة هذه المعلمة لأساليب التقويم البديل إلا أنها تتبنى النظرة التقليديـة نحو تدريس العلوم، فتتمثل في التدريس المباشـر للحقائق العلميـة وتقويمها بأسلوب الاختبـارات الكتابيـة، ويكـون عندها التمـايز بـين الطالبـات عـن طريـق الفـرق في الـدرجات،

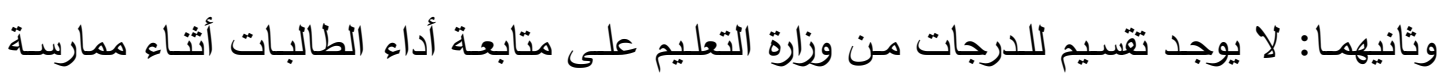
أساليب التقويم البديل.

وبالرغم من عدم معرفة أكثر من نصف العينة بمصطلح التقويم إلا أنهن استطعن ذكر دور المعلمة والطالبة أثناء استخدام التقويم البديل بشكل دقيق، وتعزي الباحثة ذلك إلى ممارسـة المعلمات التدريسية لأسـاليب التقويم البديل داخل الصف، وهذا يؤيد دراسـة الحمد (2004م)، واللبودي (2005م) اللتين أظهرتا أهمية امتلاك المعلم لمهارات توظيف التقويم البديل. ونتيجة لمعرفة المعلمات لدور المعلمة والطالبة أثناء استخدام التقويم البديل، والتثريق بين التقويم البديل والتقويم التقليدي، وقدرتهن على ذكر أمثلة صحيحة ومتنوعة على أساليب التقويم البديل التي استخدمنها الشهر الماضي عند تقويم أداء الطالبات؛ توصلت الباحثة إلى معرفتهن لأسـاليب التقويم البديل، وممارستهن التدريسية لهذه الأساليب في تقييم أداء الطالبات بشكل جيد، وتعزو الباحثة ممارسة المعلمات لأساليب التقويم البديل لوجودها في مناهج العلوم المطورة، ومتابعة المشرفات التربويات باستمرار وتتويهـن إلى ضرورة استخدام هذه الأسـاليب في التقييم، وهذا مـا أكدت عليه دراسـة الحمد (2004م) أن ممارسـة المعلمين أسـاليب التقويم البديل داخل الغرفة الصفية يجعل تقويم المعلمين لعملية تعلُّم وتعليم المتعلمين حقيقية وواقعية. ويـلازم عدم معرفـة المعلمـات بمصـلح التقويم البديل عدم معرفتهن بمصسطلح سـلم التقدير؛ لأن أكثر من ثلاثة أرباع العينة لا يعرفون سلم التقدير، لكن يمارسونه في تقييم أداء الطالبات بشكل جيد، مثل "إذا أجابت الطالبة إجابة صحيحة تأخذ الدرجة 3، بينما إذا أجابت إجابة متوسطة تأخذ الدرجة2، في حين إذا كانت إجابتها ناقصـة أو ضعيفة تأخذ الدرجـة1"، وتعزو الباحثة ذلك لوجود سلم التقدير في حقيبة المعلم للأنشطة الصفية والتقويم لمناهج العلوم، وتتوصل الباحثة إلى عدم معرفة معلمات العلوم في مدينة المجمعة للتقويم البديل وسلم التقدير كمصطلحين، وهذا يؤيد دراسـة العصفور (2006م) التي أظهرت أن امتلاك معلمي ومعلمـات المرحلة المتوسطة لمفاهيم ومصطلحات التقويم التربوي والبديل كانت ضعيفة. 


\section{مناقشة نتائج السؤال الثاني: مـا مستوى ممارسة معلمـات العلوم في ملينـة المجمعة لأساليب}

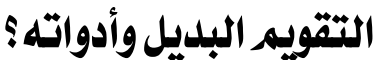

يتضح لنا من مستوى ممارسة معلمات العلوم في مدينة المجمعة لأساليب التقويم البديل

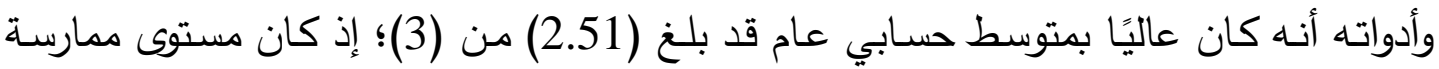

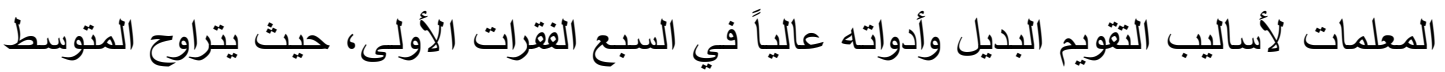

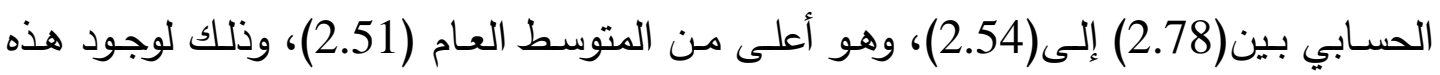

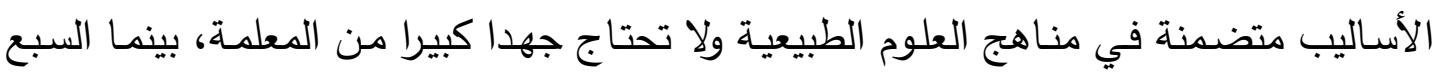

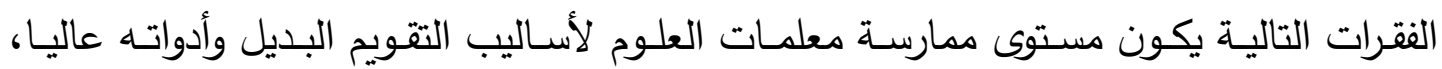

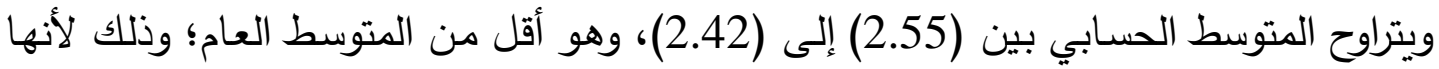

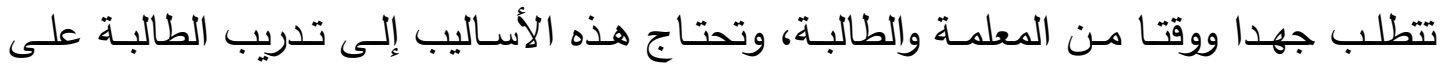

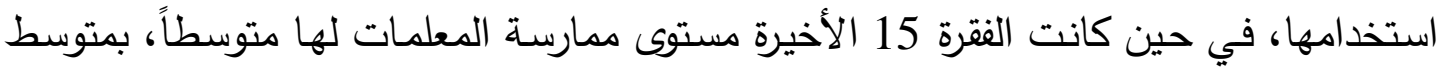

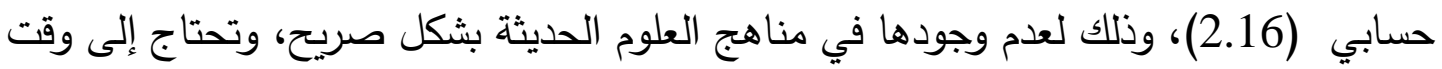

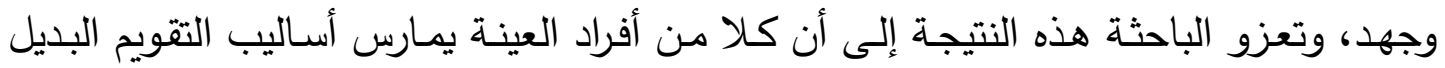

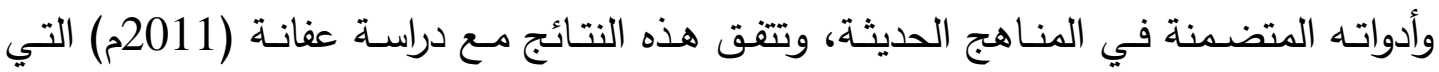

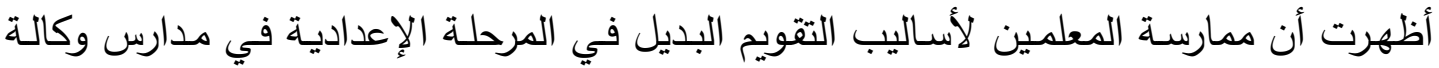

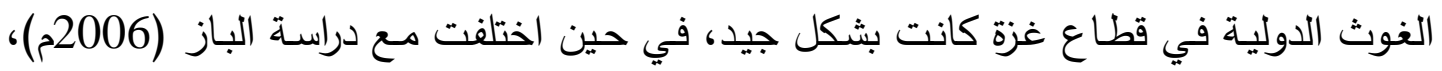

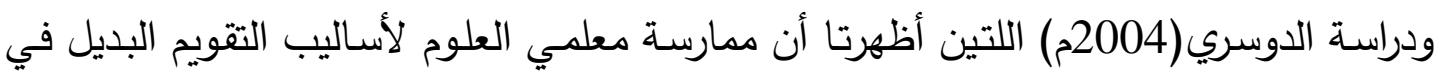

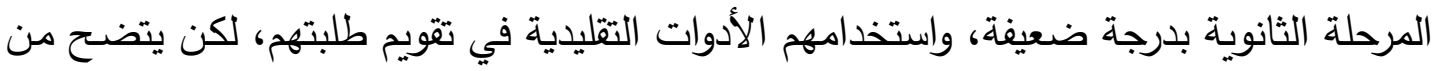
تاريخ نشر الدراستين أنهما قبل تطبيق مشروع تطوير مناهج الرياضيات والعلوم الطبيعية.

\section{مناقشـة نتـائج السؤال الثالث : مـا اتجاهـات معلمـات العلوم في ملينـة المجمعـة نحسو ممارسـة}

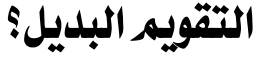

يتضح لنا أن اتجاهات معلمات العلوم نحو ممارسة التقويم البديل كانت إيجابية وعالية جدا بمتوسط عام قد بلغ (4.26) من(5)، وبذلك تمتلك معلمات العلوم اتجاهات إيجابية عالية،

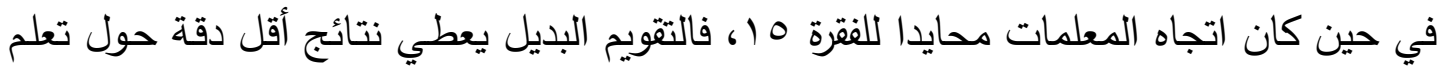
الطالبة من التقويم التقليدي، بمتوسط حسابي مقداره (3.24)، وبانحراف معياري مقداره(1.21)، وتعزو الباحثة السبب لعدم وجود تقسيم للدرجات- خاصة المرحلة المتوسطة- من وزارة التعليم على متابعة تقويم أداء الطالبة أثناء ممارسة أساليب التقويم البديل وأدواته، فيما تمتلك اتجاهات 
سلبية في الفقرة (14) حسابي مقداره (3.44)، وبانحراف معياري (1.12)، وترى الباحثة سبب

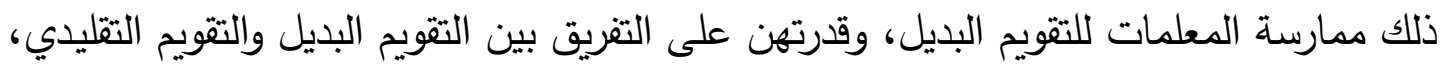

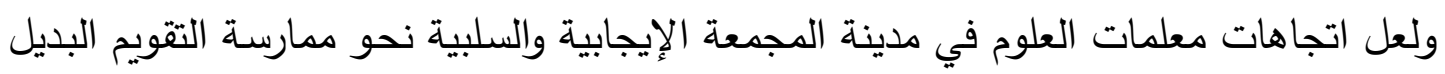

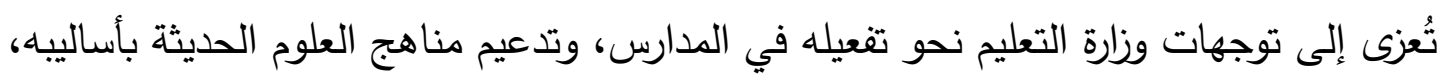

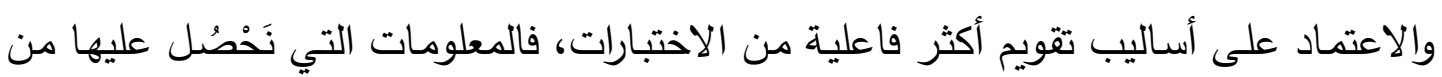

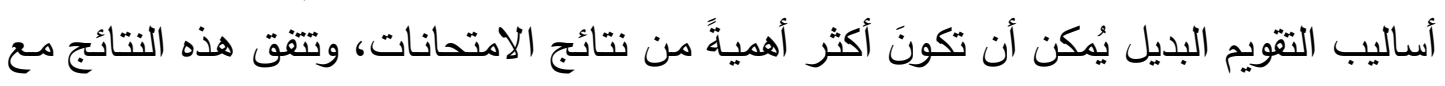

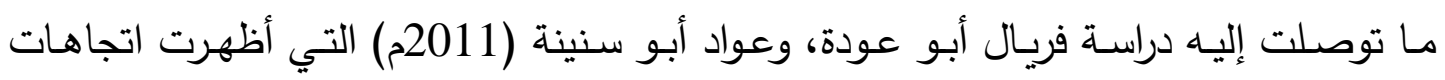
المعلمين والمعلمات الإيجابية نحو التقويم البديل باستراتيجياته وأدواته.

\section{مناقشة السؤال الرابع : ما مستوى ارتباط اتجاهات معلمات العلوم ذخو ممارسة التقويــ البـليل

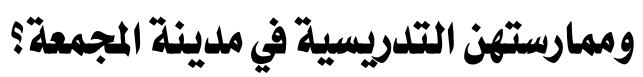

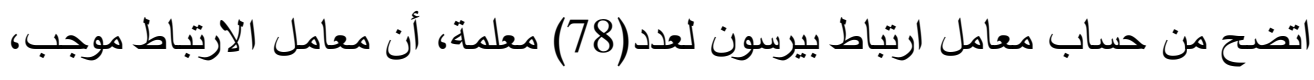

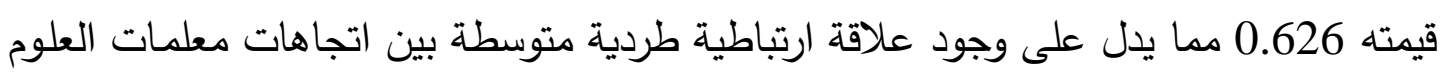

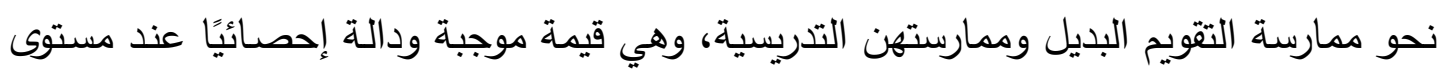

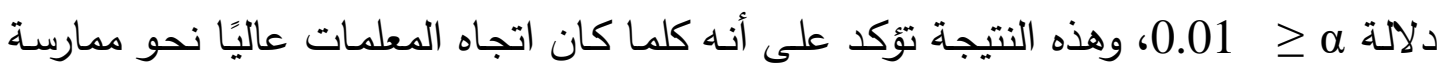

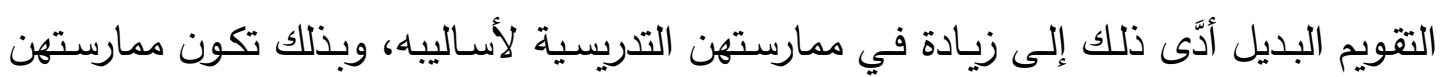
للتقويم البديل عالية.

في ضوء النتائج السابقة توصلت نتائج البحث إلى أن مستوى ممارسة معلمات العلوم

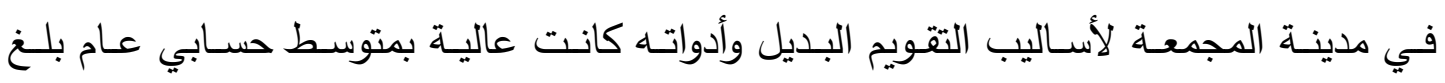

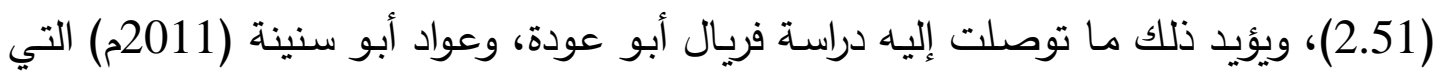

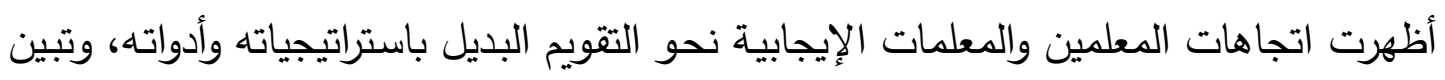

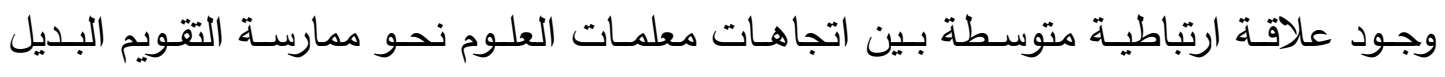

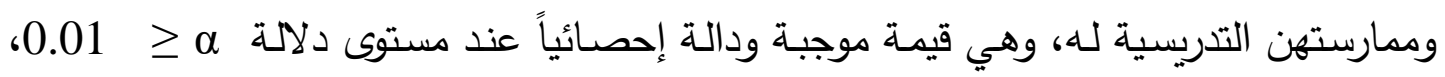

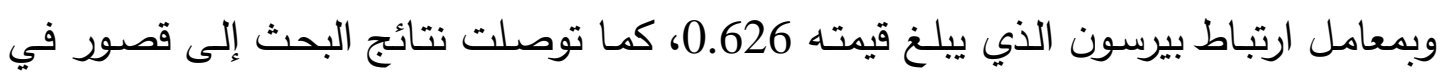

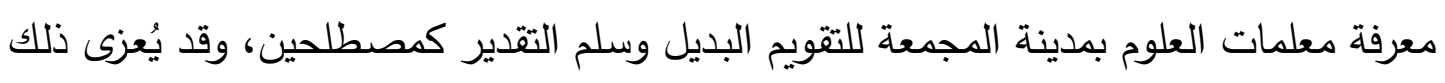
إلى أن هذه المصطلحات غير شائعة في مناهج العلوم الطبيعية وعدم وجود دورات تدريبية عن الفئل

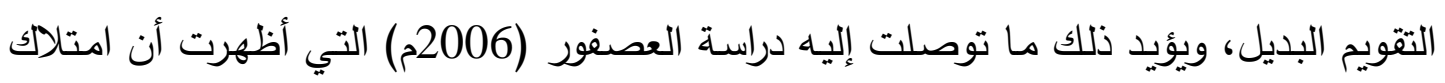

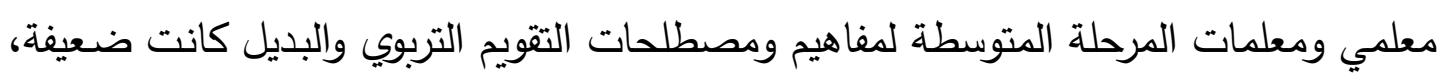


في حين أجابت المعلمات على الدفاهيم التفصيلية، كالفرق بين التقويم البديل والتقويم التقليدي،

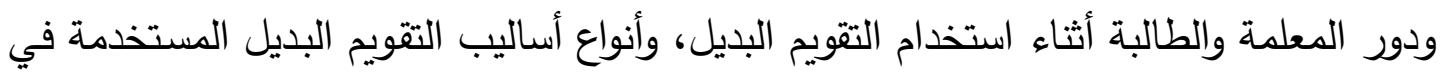

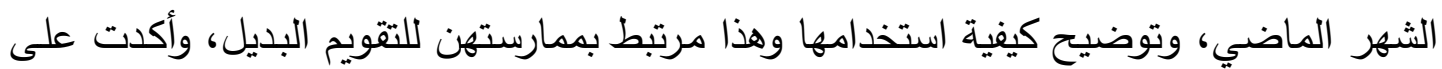

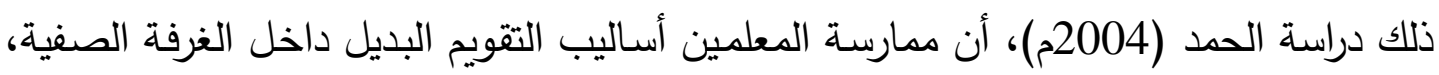

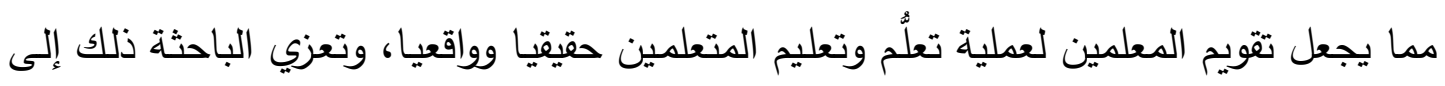

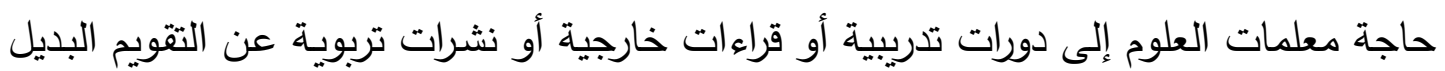

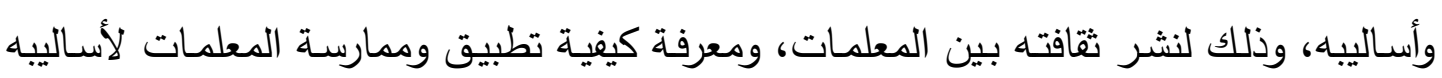

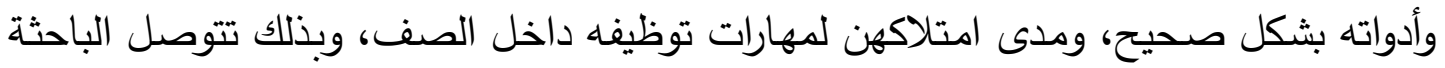
إلى أن معلمات العلوم في مدينة المجمعة يمارسن التقويم البديل أكثر من معرفتهن بهاه

في ضوء نتائج البحث الحالي فإن الباحثة ترى تقديم التوصيات التالية:

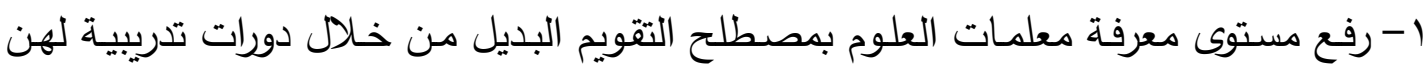
تتضمن مصطلح التقويم البديل وأساليبه وأدواته.

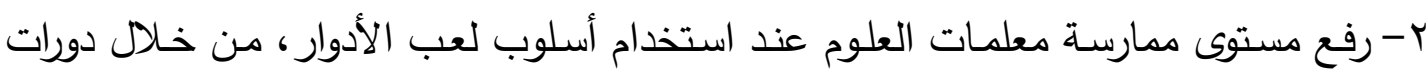

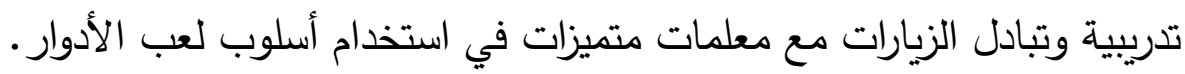
ז- معرفة مدى امتلاك معلمات العلوم لمهارات توظيف التقويم البديل داخل الصفئ.

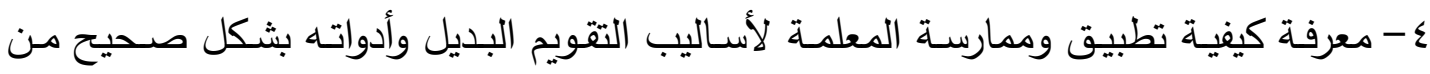

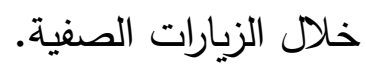
ه- العمل على وجود تقسيم للدرجات للمرحلة المتوسطة على متابعة تقويم أداء الطالبات أثناء ممارسة أساليب التقويم البديل وأدواته.

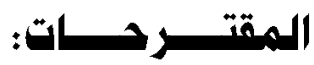

تقترح الباحثة إجراء الدراسات التالية:

1- دراسة مماثلة لهذه الدراسة لمعلمي العلوم في مدينة المجمعة، لعمل مقارنة بين تصورات معلمات ومعلمي العلوم بمدينة المجمعة حول التقويم البديل.

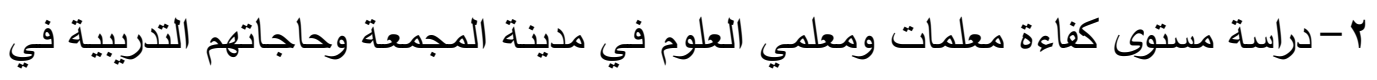
مجال التقويم البديل. r-دراسة مستوى الاستيعاب المفاهيمي لمعلمات العلوم بالمجمعة حول التقويم البديل. 


\section{قائمة المراجع والمصادر}

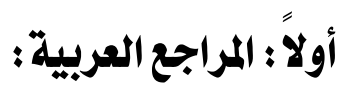

• أبوشـعيرة، خالــ؛ إثـتيوه، فـوزي؛ غبـاري، ثـائر • (2010). معيقـات تطبيـق اسـتراتيجية

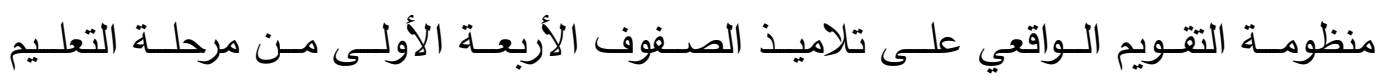

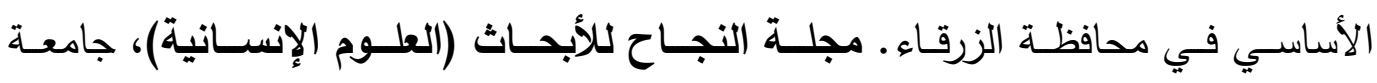

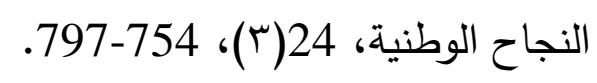

• أبو عـلام. (2001). النظريـات الحديثة في القيـاس والتقويم وتطوير نظم الامتحانـات، المركز القومي للامتحانـات والتقويم التربوي.ورقـة عمـل مقدمـة للمـؤتمر العربـي الأول (الامتحانات والتقويم التربوي: رؤية مستقبلية)، القاهرة، 22-24ديسمبر . • أبو عواد، فريال؛ أبو سنينة، عودة. (2011). معتقدات معلمي الدراسات الاجتماعية حول

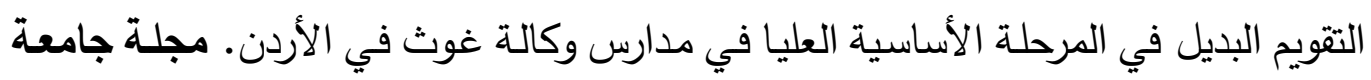

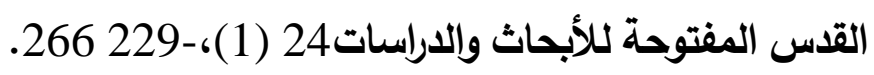
الباز ، خالد صـالح.(2006). فعاليـة برنامج مقترح لتدريب معلمي العلوم بمرحلة التعليم

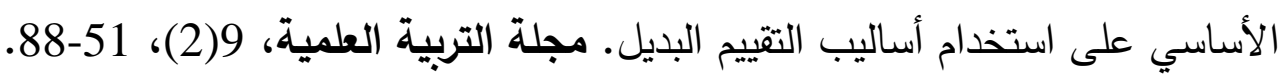
البشير ، أكرم؛ برهم، أريج. (2001). استخدام استراتيجيات التقويم البديل وأدواته في تقويم

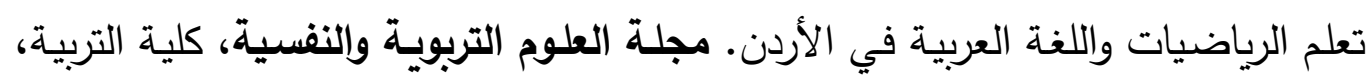
جامعة البحرين،13 (1)،270-241. " البلاونة، فهمي يونس. (2010). أثر استراتيجية التقويم القائم على الأداء في تتمية التنكير الرياضـي والقدرة على حل الشككلات ادى طلبة المرحلـة الثانويـة. مجلـة جامعـة النجـاح الوطنية، 24(8). 
• أحمد، حمدي أحمد. (2008). أثر استخدام أسـاليب التقويم الصفي البديل على تتميـة المفاهيم الاقتصـادية وتحسين فعالية الذات لدى طلاب المدارس الثانويـة التجاريـة. مجلـة كلية التربية بجامعة طنطا، 41(1)، 161-120. " حسين، محمد عبد الهادي. (2003). تربويات المـخ البشري. الطبعة الأولى، عمان: دار

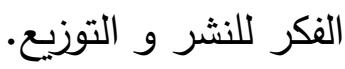
• الحمد، شيد. (2004). أسباب ضعف طلبة المرحلة الثانوية في العلوم. التقرير الختامي للموسم الثقافي السادس لقطاع البحوث التربوية والمناهج، الكويت. " الخرابشة، بنان عبدالرحمن. ( 2004). أثر استخدام أساليب التقويم البديلة في أداء طلبة الصـف التاسـع الأساسـي في التعبيـر الكتابي. رسـالة ماجستير غيـر منشـورة، الجامعـة

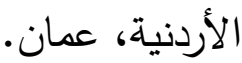

الخولي، أمين؛ الثافعي، جمال. ( 2000). مناهج التربية البذنية المعاصرة. القاهرة: دار

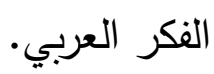
جابر ، جابر عبد الحميد؛ كاظم، أحمد خيري. ( 2011). مناهج البحث في التربية وعلم النفس. القاهرة: دار النهضة العببية. وديع ، داود.(2006).كفايات التربية العطلية. مشروع تطوير برنامج التربية العملية لإعداد

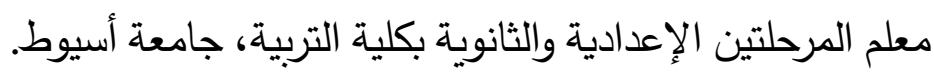
الدوسـري، إبراهيم مبارك. ( 2004). الإطـار المرجعي للتقويم التربـوي. الطبعـة الثانيـة، الرياض، مكتب التربية العربي لدول الخليج. رفيع، أحمد؛ العويشق، ناصر • (2010). مشروع تطوير مناهج الرياضيات والعلوم الطبيعية - ترجمـة ومواءمـة سلاسل عالميـة. ورقة عمل مقدمـة إلى ندوة "مشـروع تطوير منـاهج

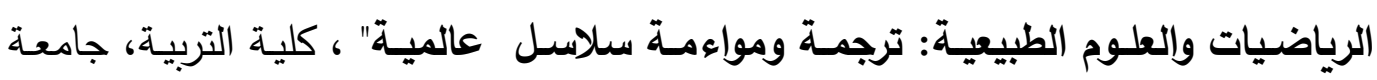
الملك سعود، بتاريخ 2010-12- ميخ 
• الرشيد، منيرة، محمد(2015): تقويم الممارسات التدريسية للى معلمات العلوم بالمرحلـة الابتدائية في ضوء التوجهات القائمة على الاقتصاد المعرفي في المملكة العربية السعودية. مجلة العلوم التربوية،27(2)، 203-228 .

" الرشيدي، عايشة (2008): تصورات معلمي العلوم في المرحلة الابتدائية في دولة الكويت لاستراتيجيات التقويم البديل ودرجة ممارستهم لها. رسالة ماجستير غير منشورة، الأردن. • زيتون، حسن.(2007). أصول التقويم والقياس التربوي المفهومات والتطبيقات. الرياض: الدار الصولتية. • زيتون، كمال عبدالحميد؛ البنا، عادل السعيد. (2001). سجلات الأداء وخرائط الدفاهيم: أدوات بديلـة في التقويم الحقيقـي مـن منظـور الفكـر البنـائي. المــؤتمر العربـي الأول

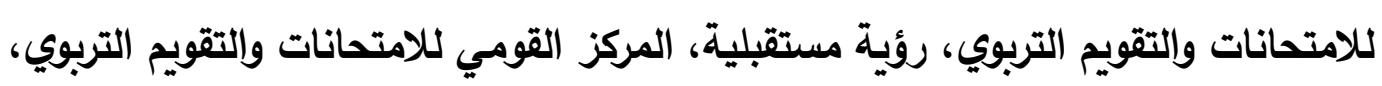
القاهرة، 24-22ديسمبر، 218-178.

سرايا، عادل.(2005). التقويم الحقيقي. مجلة التدريب والتقنية، 74(1)،410-40. • السويهري، عبدالرحمن.(2013).تقويم اختبارات ومقاييس التقويم البديل في مادة الرياضيات للصفوف العليا في المرحلة الابتدائية بككة المكرمة. رسالة ماجستير غير منشورة، جامعة

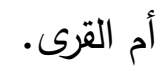

الثايع، فهد ؛ عبدالحميد، عبدالناصر • (2011). مشروع تطوير مناهج الرياضيات والعلوم

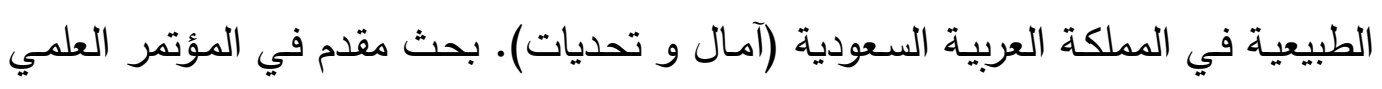
الخامس عشر الجمعية المصرية للتربية العلمية "فكر جديد لواقع جديد"، سبتمبر . الشريف، فهد.(2014). برنامج مقترح لتتمية مهارات استخدام أساليب التقويم البديل لدى معلمي

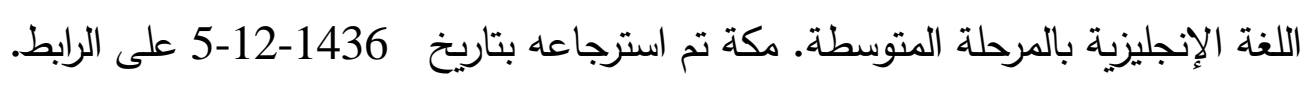
http://webcache.googleusercontent.com/search?q=cacheQEcs5QWbWoJ:www.m5zn.com/newuploads/2014/03/25 
" الفريق الوطني للتقويم. (2004). استراتيجيات التقويم وأدواته :الإطار النظري، إدارة الامتحانات والاختبارات. وزارة التربية والتعليم، الأردن.

عبد الباقي، إيمان سعيد. (2005). فعالية برنامج مقترح لتدريب معلمي العلوم على أساليب التقويم الواقعي. رسالة دكتوراه غير منشورة، جامعة عين شمس، كلية البنات للآداب والعلوم

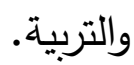
• العربي، محمــ(2004). فعاليـة التقويم البديل على التحصيل والتواصـل وخفض قلق الرياضيات لتلاميذ المرحلة الابتدائيـة. بحثث مقدم في المؤتمر العلمي الرابـع للجمعيـة المصرية لتربويات الرياضيات، 7-8 يوليو. • العصفور ، ناصر بخيت(2006). مستوى كفاءة معلمي ومعلمات المرحلة المتوسطة في مدارس دولة الكويت وحاجاتهم التدريبية في مجال القياس التقويم التربوي. رسالة ماجستير غير منشورة، جامعة عمان العربية للدراسات العليا، الأردن. • علام، صلاح الدين محمود. (2004). التقويم التربوي البديل : أسسه النظريـة والمنهجية وتطبيقاته الميدانية. القاهرة: دار الفكر العربي. غنيم، محمد أحمد. (2003). مشكلات تقويم التحصيل الدراسي بين النظريتين الكلاسيكية والمعاصرة في القياس النفسي، بحث مقدم للجنة العلمية الدائمة لعلم النفس التربوي والصحة النفسية لوظائف الأساتذة، القاهرة. • مدبولي، محمد عبدالخالق. (2004). تطوير مسـاق الأصسول الفلسفية للتربيـة في ضدوء فلسفة التقييم المستند إلى الأداء: دراسة تطبيقية. دراسـات تربويـة واجتماعيـة، كلية التربية، جامعة حلوان، 10(1). • مـراد، خلود.(2001). أسـاليب التقويم للاى معلمي ومعلمـات الحلقة الأولى مـن التعليم

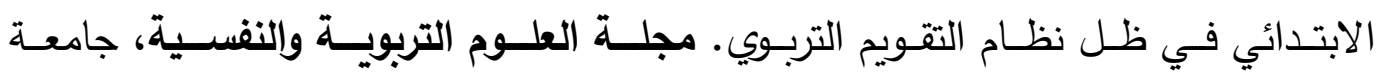
البحرين،2(2)، 193-192. 
• المقحم، علي.(2015). مدى ممارسة معلمي ومعلمات مقررات اللغة العربية في مراحل

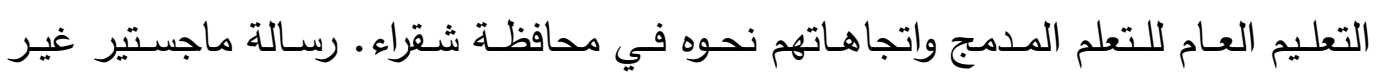
منشورة، الرياض.

• مهيدات، عبدالحكيم علي؛ المحاسنة، إبراهيم محمد. (2009). التقويم الواقعي. عمان: دار جرير للنشر والتوزيع.

اللبودي، دنـى ابـراهيم. (2005). صـعوبات القـراءة والكتابـة: تثخيصـها واســتراتيجية وعلاجها. الطبعة الأولى. مكتبة زهراء الثرق.

ه اللويد دوايت. (2009). أساسيات التقييم في التعليم اللغوي. ترجمـة: خالد عبدالعزيز الدافع، الطبعة الأولى، الرياض، مطابع جامعة الملك سعود. • وهبة، نادر عطا الله. (2001). التقويم الأصيل ما بين التقليد والحداثة. نشرة رؤى تربوية،

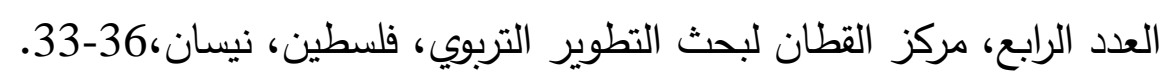

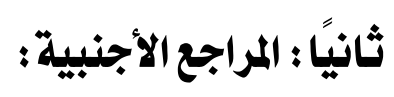

- Cooney,T.(1996).The demands of alternative assessment: What teachers say. The mathematics teacher 89(6), 484-488.

- Culbertson, L,D.(2000). Alternative assessment: Primary grade literacy teachers knowledge, attitudes, and practices.D.Ed. dissertation, Indiana University of Pennsylvania,United StatesPennsylvania.Retrieved August 6, 2015, from Dissertations \& Theses: Full Text.( publication No. AAT9961569).

- Drury, J,H.(1994). Asurvey to investigate teacher awareness of alternative assessment of students in mathematics. Ph.D.dissertation, The Ohio State University, United States, Ohio. 
- Retrieved August 9, 2015, from Dissertations \& Theses: Full Text.( publication No. AAT9427700). ulikers, T.(2004). A FiveDimensional Framework for Authentic Assessment. Educational Technology Research \& Development,52(3),67-86.

- Lanting,A.Y.(2000). An empirical study of district-wide k-2 performance assessment program:Teacher practices, information gained, and use of assessment results. Dissertation Abstracts. $\mathrm{PhD}$, University of Illinois At Urbana-Champaign,USA.

- Muirhead, B.(2002). Relevant assessment for strategies online

- colleges and university. Usdla journal,16(2) ISN:1537-5080.

- Mueller.(2008). The Authentic Assessment Toolbox Enhancing student learning Through on line Faculty Development. Retrieved 12/7/2015 From http:// jfmueller faculty. noctrl.edu.

- Olson,L.(1999)."In Search of Better Assessment". Education Week,1999,11,1720.

- Peterson, C,G.(1994).A study of elementary principals and teachers knowledge about al ternative assessment and its implementation in classrooms. Ph.D. dissertation, University of South Carolina, United States, South Carolina. Retrieved August 6, 2015, from Dissertations\& Theses: Full Text.( publication No. AAT9517305).

- Wright, W. A. (1993,May). Implications of perceptions of teacher implementing authentic assessment, lln published doctorate thesis, The School of Education, Drake University. 


\section{Ahstract}

This study targets surveying science teachers' perception in AlMajama'a about assessment alternative's knowledge, practice and perception. Descriptive approach is used and two tools; double questionnaire to collect quantitative data about the teachers' practice, its tools and their perspectives. After testing sincerity, it is applied on the society (108 teachers), (78 respondents). The tool's stability is (0.91). Qualitative data on teachers' knowledge is collected using semistandardized tool. When sincerity is tested, it is used on 10 teachers.

Results showed teachers' practice level and its tools are high by (2.51), while their perspective is positive by (4.26). That shows moderate correlation between the teachers' perspectives and their educational practices. Which is a statistically significant value at a $0.01 \geq$. While The Pearson correlation coefficient is (0.626). Results showed deficiency in knowledge and rating scale as terms due to their uncommon use in science. However, they responded well on details such as difference between alternative and traditional, role of teacher and student and kinds of its methods. All are related to educational practice; alterative evaluation is more engaged than known.

Therefore, recommendations are provided; raising science teachers' knowledge of assessment alternative term and practice through training courses cover term, methods and tools. 